Prepared in cooperation with the Arkansas Department of Environmental Quality

\title{
Application of a Two-Dimensional Reservoir Water-Quality Model of Beaver Lake, Arkansas, for the Evaluation of Simulated Changes in Input Water Quality, 2001-2003
}

Scientific Investigations Report 2006-5302 
Cover: View of Beaver Lake from the south side of Beaver Lake Dam (Photograph used with permission from Chuck Haralson, Arkansas Department of Parks and Tourism.) 


\section{Application of a Two-Dimensional Reservoir Water-Quality Model of Beaver Lake, Arkansas, for the Evaluation of Simulated Changes in Input Water Quality, 2001-2003}

By Joel M. Galloway and W. Reed Green

In cooperation with the Arkansas Department of Environmental Quality

Scientific Investigations Report 2006-5302 


\section{U.S. Department of the Interior DIRK KEMPTHORNE, Secretary}

\section{U.S. Geological Survey \\ Mark D. Myers, Director}

\section{U.S. Geological Survey, Reston, Virginia: 2007}

For product and ordering information:

World Wide Web: http://www.usgs.gov/pubprod

Telephone: 1-888-ASK-USGS

For more information on the USGS--the Federal source for science about the Earth, its natural and living resources, natural hazards, and the environment:

World Wide Web: http://www.usgs.gov

Telephone: 1-888-ASK-USGS

Any use of trade, product, or firm names is for descriptive purposes only and does not imply endorsement by the U.S. Government.

Although this report is in the public domain, permission must be secured from the individual copyright owners to reproduce any copyrighted materials contained within this report.

Suggested citation:

Galloway, J.M., and Green, W.R., 2007, Application of a two-dimensional reservoir water-quality model of Beaver Lake, Arkansas, for the evaluation of simulated changes in input water quality, 2001-2003: U.S. Geological Survey Scientific Investigations Report 2006-5302, 31 p. 


\section{Contents}

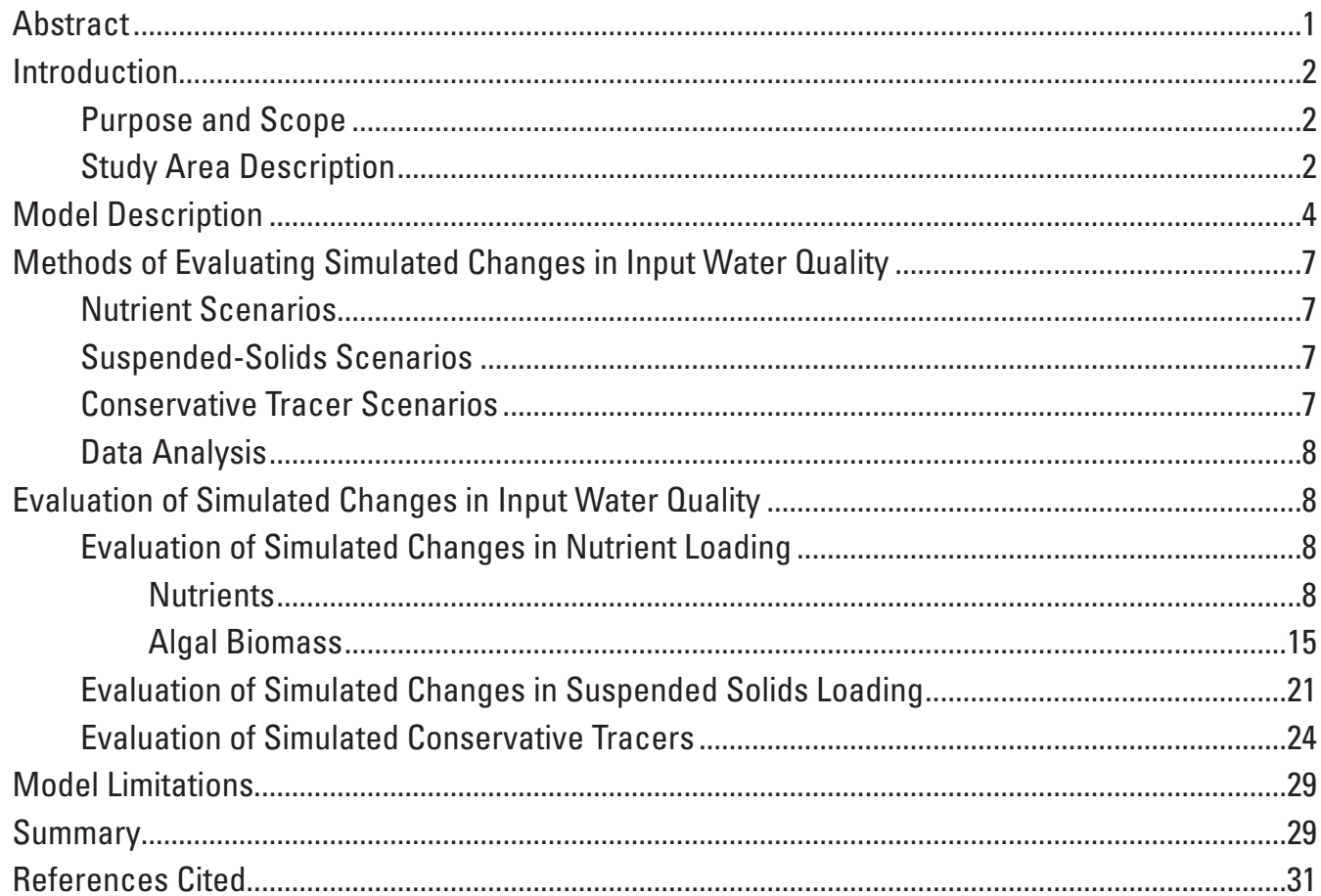

\section{Figures}

1. Map showing Beaver Lake Basin with streamflow and lake water-quality measurement sites.3

2. Map showing land use in the Beaver Lake Basin

3. Graph showing daily inflow and reservoir water-surface elevation for Beaver Lake,

Arkansas, April 2001 to April 2003

4. Diagram showing locations of conservative tracer injection points and water-supply intakes on the Beaver Lake model grid

5-18. Graphs showing:

5. Mean daily differences in total nitrogen concentrations at four sites in Beaver Lake resulting from simulated changes in the calibrated daily input nitrogen and phosphorus concentrations, April 2001 to April 2003.

6. Mean daily differences in total nitrite plus nitrate concentrations at four sites in Beaver Lake resulting from simulated changes in the calibrated daily input nitrogen and phosphorus concentrations, April 2001 to April 2003.

7. Mean daily differences in ammonia concentrations at four sites in Beaver Lake resulting from simulated changes in the calibrated daily input nitrogen and phosphorus concentrations, April 2001 to April 2003.

8. Mean daily differences in orthophosphorus concentrations at four sites in Beaver Lake resulting from simulated changes in the calibrated daily input nitrogen and phosphorus concentrations, April 2001 to April 2003

9. Mean daily differences in total phosphorus concentrations at four sites in Beaver Lake resulting from simulated changes in the calibrated daily input nitrogen and phosphorus concentrations, April 2001 to April 2003 
10. Mean daily differences in simulated chlorophyll $a$ concentrations at four sites in Beaver Lake resulting from simulated changes in the calibrated daily input nitrogen and phosphorus concentrations, April 2001 to April 2003.

11. Time series of daily differences in simulated chlorophyll $a$ values in the epilimnion at Beaver Lake at Lowell, Arkansas (site L3), resulting from simulated changes in the calibrated daily input nitrogen and phosphorus concentrations, April 2001 to April 2003.

12. Time series of daily differences in simulated chlorophyll $a$ values in the epilimnion at Beaver Lake at Lowell, Arkansas (site L3), resulting from simulated changes in the calibrated daily input nitrogen concentrations, April 2001 to April 2003.

13. Time series of daily differences in simulated chlorophyll $a$ values in the epilimnion at Beaver Lake at Lowell, Arkansas (site L3), resulting from simulated changes in the calibrated daily input phosphorus concentrations, April 2001 to April 2003.

14. Mean differences in simulated chlorophyll $a$ concentrations in the main branch of the Beaver Lake model resulting from a simulation of 10 times the calibrated daily input nitrogen and phosphorus concentrations on September 12, 2001 and May 11, 2002.

15. Mean daily differences in total suspended-solids concentrations at four sites in Beaver Lake resulting from simulated changes in daily input inorganic suspended-solids concentrations, April 2001 to April 2003.

16. Mean differences in simulated inorganic suspended-solids concentrations in the main branch of the Beaver Lake model resulting from a simulation of 10 times the daily input inorganic suspended-solids concentrations on March 3, 2001 and April 15, 2002.

17. Time series of simulated conservative tracer concentrations at four water-supply intakes when tracer was introduced in Beaver Lake at high-flow conditions on March 17, 2002

18. Time series of simulated conservative tracer concentrations at four water-supply intakes when tracer was introduced in Beaver Lake at low-flow conditions on August 7, 2001

\section{Table}

1. Average daily simulated concentrations for the calibrated model of Beaver Lake. .9

2. Simulated conservative tracer results at four water-supply intakes in Beaver Lake,

2001-2003 


\section{Conversion Factors and Datums}

\begin{tabular}{lcl}
\hline \multicolumn{1}{c}{ Multiply } & By & \multicolumn{1}{c}{ To obtain } \\
\hline meter $(\mathrm{m})$ & 3.281 & foot $(\mathrm{ft})$ \\
cubic meter $\left(\mathrm{m}^{3}\right)$ & 35.31 & cubic foot $\left(\mathrm{ft}^{3}\right)$ \\
kilometer $(\mathrm{km})$ & 0.6214 & mile $(\mathrm{mi})$ \\
square kilometer $\left(\mathrm{km}^{2}\right)$ & 247.1 & square mile $\left(\mathrm{mi}^{2}\right)$ \\
cubic meter per second $\left(\mathrm{m}^{3} / \mathrm{s}\right)$ & 35.31 & cubic foot per second $\left(\mathrm{ft}^{3} / \mathrm{s}\right)$ \\
kilogram $(\mathrm{kg})$ & 2.205 & pound $(\mathrm{lb})$ \\
\hline
\end{tabular}

Temperature in degrees Celsius $\left({ }^{\circ} \mathrm{C}\right)$ may be converted to degrees Fahrenheit $\left({ }^{\circ} \mathrm{F}\right)$ as follows:

$$
{ }^{\circ} \mathrm{F}=\left(1.8 \mathrm{x}^{\circ} \mathrm{C}\right)+32
$$

Vertical coordinate information is referenced to the National Geodetic Vertical Datum of 1929 (NGVD of 1929). 


\title{
Application of a Two-Dimensional Reservoir Water- Quality Model of Beaver Lake, Arkansas, for the Evaluation of Simulated Changes in Input Water Quality, 2001-2003
}

\author{
By Joel M. Galloway and W. Reed Green
}

\section{Abstract}

Beaver Lake is considered a primary watershed of concern in the State of Arkansas. As such, information is needed to assess water quality, especially nutrient enrichment, nutrient-algal relations, turbidity, and sediment issues within the system. A previously calibrated two-dimensional, laterally averaged model of hydrodynamics and water quality was used for the evaluation of changes in input nutrient and sediment concentrations on the water quality of the reservoir for the period of April 2001 to April 2003. Nitrogen and phosphorus concentrations were increased and decreased and tested independently and simultaneously to examine the nutrient concentrations and algal response in the reservoir. Suspended-solids concentrations were increased and decreased to identify how solids are distributed in the reservoir, which can contribute to decreased water clarity. The Beaver Lake model also was evaluated using a conservative tracer. A conservative tracer was applied at various locations in the reservoir model to observe the fate and transport and how the reservoir might react to the introduction of a conservative substance, or a worst-case spill scenario. In particular, tracer concentrations were evaluated at the locations of the four public water-supply intakes in Beaver Lake.

Nutrient concentrations in Beaver Lake increased proportionally with increases in loads from the three main tributaries. An increase of 10 times the calibrated daily input nitrogen and phosphorus in the three main tributaries resulted in daily mean total nitrogen concentrations in the epilimnion that were nearly 4 times greater than the calibration concentrations at site L2 and more than 2 times greater than the calibrated concentrations at site L5. Increases in daily input nitrogen in the three main tributaries independently did not correspond in substantial increases in concentrations of nitrogen in Beaver Lake.

The greatest proportional increase in phosphorus occurred in the epilimnion at sites L3 and L4 and the least increase occurred at sites L2 and L5 when calibrated daily input phosphorus concentrations were increased. When orthophosphorus was increased in all three tributaries simul- taneously by a factor of 10 , daily mean orthophosphorus concentrations in the epilimnion of the reservoir were almost 11 times greater than the calibrated concentrations at sites L2 and L5, and 15 times greater in the epilimnion of the reservoir at sites L3 and L4. Phosphorus concentrations in Beaver Lake increased less when nitrogen and phosphorus were increased simultaneously than when phosphorus was increased independently.

The greatest simulated increase in algal biomass (represented as chlorophyll $a$ ) occurred when nitrogen and phosphorus were increased simultaneously in the three main tributaries. On average, the chlorophyll $a$ values only increased less than 1 microgram per liter when concentrations of nitrogen or phosphorous were increased independently by a factor of 10 at all three tributaries. In comparison, when nitrogen and phosphorus were increased simultaneously by a factor of 10 for all three tributaries, the chlorophyll $a$ concentration increased by about 10 micrograms per liter on average, with a maximum increase of about 57 micrograms per liter in the epilimnion at site L3 in Beaver Lake. Changes in algal biomass with changes in input nitrogen and phosphorus were variable through time in the Beaver Lake model from April 2001 to April 2003. When calibrated daily input nitrogen and phosphorus concentrations were increased simultaneously for the three main tributaries, the increase in chlorophyll $a$ concentration was the greatest in late spring and summer of 2002.

Changes in calibrated daily input inorganic suspended solids concentrations were examined because of the effect they may have on water clarity in Beaver Lake. The increase in total suspended solids was greatest in the hypolimnion at the upstream end of Beaver Lake, and negligible changes were observed at the downstream end of the reservoir for all of the scenarios. An increase of 10 times the calibrated daily input concentration of inorganic suspended solids in all three tributaries resulted in an increase in daily mean total suspended solids concentration of more than 5 times the calibrated condition in the epilimnion and more than 10 times the calibrated condition in the hypolimnion at site L2. Concentrations were similar to the calibrated condition in the epilimnion and more than 11 times the calibrated condition in the hypolimnion at site L3. 
A conservative tracer was introduced into the model at eight locations in the reservoir during high-flow (March 17, 2002) and low-flow (August 7, 2001) conditions. In general, the duration of high tracer concentrations at the four water-supply intakes was relatively short when tracers were released at highflow conditions compared to releases during low-flow conditions. When tracers were placed in the more riverine portion of the reservoir, the tracer was rapidly transported into the hypolimnion in the upstream portion of the reservoir and into the epilimnion and metalimnion further downstream in the reservoir during high-flow conditions. In comparison, when tracers were introduced during low-flow conditions, most of the tracer remained in the upstream portion of the reservoir until mid-December when a storm event flushed most of the tracer downstream into the hypolimnion, mainly at greater depths than the downstream water-supply intakes.

\section{Introduction}

Beaver Lake is a large, deep-storage reservoir located in the White River Basin in northwestern Arkansas (fig. 1). The reservoir was completed in 1963 for the purposes of flood control, hydroelectric power, and water supply. In addition, the reservoir is used for fish and wildlife habitat, recreation, and waste assimilation. Because of the importance of Beaver Lake, it is considered a primary watershed of concern in the State of Arkansas. Information is needed to assess water quality, especially nutrient enrichment, nutrient-algal relations, turbidity, and sediment issues within the system.

Beaver Lake is affected by both point and nonpoint sources of contamination. The city of Fayetteville discharges about one-half of its sewage effluent into the White River immediately upstream from the backwater of the reservoir. The city of West Fork discharges its sewage effluent into the West Fork of the White River, and the city of Huntsville discharges its effluent into a tributary of War Eagle Creek. Nutrients, sediment, pathogenic bacteria, and other constituents also can enter Beaver Lake through its tributaries and around its shoreline. The greatest increase in population in the State of Arkansas from 1990 to 2000 occurred in Benton, Washington, and Carroll Counties in northwestern Arkansas, surrounding Beaver Lake (fig. 1). The principal agricultural activity in the area is poultry production. As a result of all these factors, there is much concern about the current and future water quality of Beaver Lake.

In cooperation with the Arkansas Department of Environmental Quality (ADEQ), a previously calibrated two-dimensional, laterally averaged model of hydrodynamics and water quality (Galloway and Green, 2006) was used for the evaluation of different nutrient and sediment loading and conservative tracer simulations for the period of April 2001 to April 2003. Results of the nutrient and sediment loading simulations for Beaver Lake will assist ADEQ in the development of waterquality criteria for designated uses in lakes and reservoirs. Historically, Arkansas' water-quality standards for lakes have been adapted from the surface water-quality standards for streams. Although the designated uses that are assigned to Arkansas' lakes and reservoirs may be appropriate, the criteria set forth to protect them may not be adequate. Various levels of nutrient and sediment loading were used to evaluate reservoir response to changes in the input loading. Conservative tracer simulations were used to evaluate the time of travel of a conservative constituent from different locations on Beaver Lake to the four public water-supply intakes for response to possible spills that could occur on the reservoir.

\section{Purpose and Scope}

The purpose of this report is to describe the application of a previously calibrated model of hydrodynamics and water quality of Beaver Lake (Galloway and Green, 2006) for the evaluation of changes in inputs of nutrients and sediment on the water quality of the reservoir for the modeling period of April 2001 to April 2003. Nitrogen and phosphorus concentrations were increased and decreased in the White River, Richland, and War Eagle Creeks, and tested independently and simultaneously to examine the nutrient concentrations and algal response in the reservoir. Suspended-solids concentrations were increased and decreased to identify how solids, which can contribute to decreased water clarity, are distributed in the reservoir. These results can be used in the development of nutrient and turbidity criteria and standards for Beaver Lake. The methods also can be used as a prototype for assessing water-quality criteria in other reservoirs. The Beaver Lake model also was evaluated using a conservative tracer. A conservative tracer was applied at various locations in the reservoir model to observe the fate and transport and how the reservoir might react to the introduction of a conservative substance, or a worst-case spill scenario. In particular, tracer concentrations were evaluated at the locations of the four public water-supply intakes in Beaver Lake.

\section{Study Area Description}

Beaver Lake was impounded in 1963 on the White River, northeast of the city of Fayetteville, Arkansas, and in 1968 the reservoir reached conservation pool elevation (Haggard and Green, 2002). Beaver Lake contains 2,040 million $\mathrm{m}^{3}$ of water when the water-surface elevation is at the top of the current conservation pool (341.4 $\mathrm{m}$ above NGVD of 1929) and the surface area is $114 \mathrm{~km}^{2}$ (Haggard and Green, 2002). The length of the reservoir is $80 \mathrm{~km}$ from the White River at the Highway 45 Bridge to the Beaver Lake dam. The depth of the reservoir at the dam at conservation pool elevation is $60 \mathrm{~m}$, and the average depth through the reservoir is $18 \mathrm{~m}$ (Haggard and Green, 2002).

Beaver Lake has three distinct zones with unique and dynamic physical, chemical, and biological characteristics 


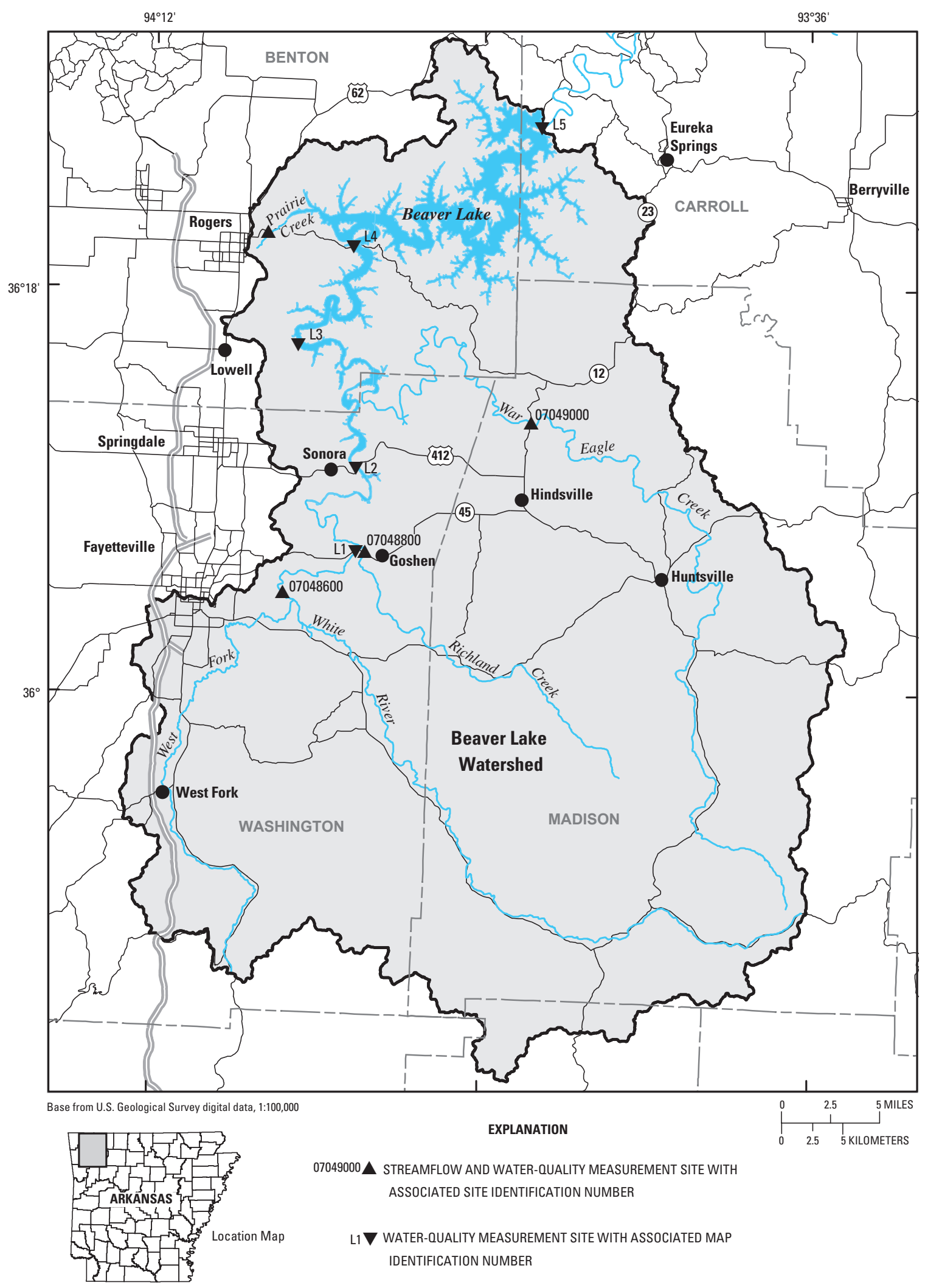

Figure 1. Beaver Lake Basin with streamflow and lake water-quality measurement sites. 


\section{Application of a Two-Dimensional Reservoir Water-Quality Model of Beaver Lake, Arkansas, for the Evaluation of Simulated Changes in Input Water Quality, 2001-2003}

that are typical for large reservoirs; a riverine zone, a transitional zone, and a lacustrine zone (Wetzel, 2001). The riverine zone is relatively narrow. The water is well-mixed, and velocities are substantial enough to move fine suspended particles (silts, clays, and particulate matter) through advective transport. High particulate turbidity reduces light penetration and limits algal production in this zone (Wetzel, 2001). Decomposition of organic matter usually is high, which consumes a substantial amount of dissolved oxygen in the water column. In the transitional zone, water velocities decrease as energy is dispersed over a larger area. A large portion of the suspended load settles out of the water column, enhancing the depth of light penetration, which increases the rates of photosynthetic productivity of algae in this zone. Anoxic conditions in the hypolimnion in the transitional zone usually occur early in the stratification season of the reservoir from sediment and biochemical demand from deposited material. The lacustrine zone (or lake-like zone) is characterized by having distinct stratification, with limited nutrient concentrations resulting in reduced algal production. Sedimentation of organic matter and decomposition in the lacustrine zone is more limited than in the riverine and transitional zone, generally resulting in lower concentrations of nutrients and higher dissolved oxygen in the hypolimnion. The extent of the three zones can be spatially and temporally dynamic with changing inflow and outflow conditions in the reservoir.

The main inflows into Beaver Lake are the White River, Richland Creek, and War Eagle Creek (fig. 1). Several smaller tributaries also flow into the reservoir. The Basin has a drainage area of 2,961 km² upstream from Beaver Lake dam. The Basin is composed of approximately 57 percent forested land, 32 percent agricultural land (mainly pasture land), and 5 percent urban land use (fig. 2). Approximately 6 percent of the basin is covered by Beaver Lake.

The White River is the largest tributary to Beaver Lake with a drainage area of $1,036 \mathrm{~km}^{2}$ upstream from the streamflow gaging station near Fayetteville (White River near Fayetteville, Arkansas, station number 07048600), composing approximately 35 percent of the drainage area of Beaver Lake at the dam. The White River watershed is approximately 72 percent forested land, 23 percent agricultural land (mainly pasture land), 2.4 percent urban land use, and 2.6 percent other land uses (U.S. Geological Survey, 2002). The White River near Fayetteville had a mean daily streamflow of $15.7 \mathrm{~m}^{3} / \mathrm{s}$ for the period of record (1963-1994, 1998-2004) (Brossett and others, 2005). The mean daily streamflow for the modeling period (April 2001 to April 2003) was $13.6 \mathrm{~m}^{3} / \mathrm{s}$ (Galloway and Green, 2006) (fig. 3).

War Eagle Creek is the second largest tributary to Beaver Lake with a drainage area of $688 \mathrm{~km}^{2}$ at the streamflow gaging station near Hindsville (War Eagle Creek near Hindsville, Arkansas, station number 07049000), composing approximately 23 percent of the Beaver Lake Basin upstream from the dam. The basin is approximately 61 percent forested land, 36 percent agricultural land (mostly pasture), 0.5 percent urban land use, and 2.5 percent other land uses (fig. 2). The daily mean streamflow for War Eagle Creek near Hindsville was $7.87 \mathrm{~m}^{3} / \mathrm{s}$ for the period of record (1952-1970, 1998-2004) (Brossett and others, 2005) and $7.30 \mathrm{~m}^{3} / \mathrm{s}$ for the modeling period (Galloway and Green, 2006) (fig. 3).

Richland Creek is another major tributary to Beaver Lake, with a drainage area of $369 \mathrm{~km}^{2}$ upstream from the streamflow gaging station at Goshen (Richland Creek at Goshen, Arkansas, station number 07048800), composing approximately 12 percent of the drainage area of Beaver Lake upstream from the dam. The land use in the Richland Creek Basin includes about 63 percent forested land, 34.5 percent agricultural land (mostly pasture land), less than 0.5 percent urban land use, and 2 percent other land uses (fig. 2) (U.S. Geological Survey, 2002). The mean daily streamflow for the period of record (1998 to 2004) for Richland Creek at Goshen was $4.05 \mathrm{~m}^{3} / \mathrm{s}$ (Brossett and others, 2005) and the mean daily streamflow for the modeling period was $3.47 \mathrm{~m}^{3} / \mathrm{s}$ (Galloway and Green, 2006) (fig. 3).

\section{Model Description}

A two-dimensional, laterally averaged, hydrodynamic and water-quality model using CE-QUAL-W2 Version 3.1 (Cole and Wells, 2003) previously was developed for Beaver Lake and was calibrated based on vertical profiles of temperature and dissolved oxygen, and water-quality constituent concentrations collected at various depths at four sites in the reservoir from April 2001 to April 2003 (Galloway and Green, 2006). The CE-QUAL-W2 model simulates water-surface elevation and vertical and longitudinal gradients of water-quality constituents. The model simulates 18 variables in addition to temperature, including an inorganic suspended-solids group, four phytoplankton groups, a carbonaceous biochemical oxygen demand group, nitrogen and phosphorus species, dissolved and particulate organic matter, total inorganic carbon, dissolved oxygen, and organic sediments. Further description of the Beaver Lake model development can be found in Galloway and Green (2006).

The calibrated Beaver Lake model (Galloway and Green, 2006) simulated temperatures that compared reasonably well with measured temperatures and differences varied spatially in Beaver Lake from April 2001 to April 2003. The absolute mean error (AME) ranged from $3.1^{\circ} \mathrm{C}$ at site $\mathrm{L} 2$ to $0.8^{\circ} \mathrm{C}$ at $\mathrm{L} 5$ and the root mean square error (RMSE) ranged from $3.2^{\circ} \mathrm{C}$ at site L2 to $0.9^{\circ} \mathrm{C}$ at site L5 from April 2001 to April 2003 (fig. $1)$. The greatest differences between simulated and measured data occurred in the upstream portion of the reservoir, which is the most dynamic part of the reservoir. In general, the AME and RMSE were the lowest in 2001 at the upper two sites (L2 and L3) and in 2002 for the lower two sites (L4 and L5) and greatest in 2003 for all four sites.

Simulated water quality was similar to measured waterquality conditions in Beaver Lake from April 2001 to April 2003, with differences between simulated and measured values 


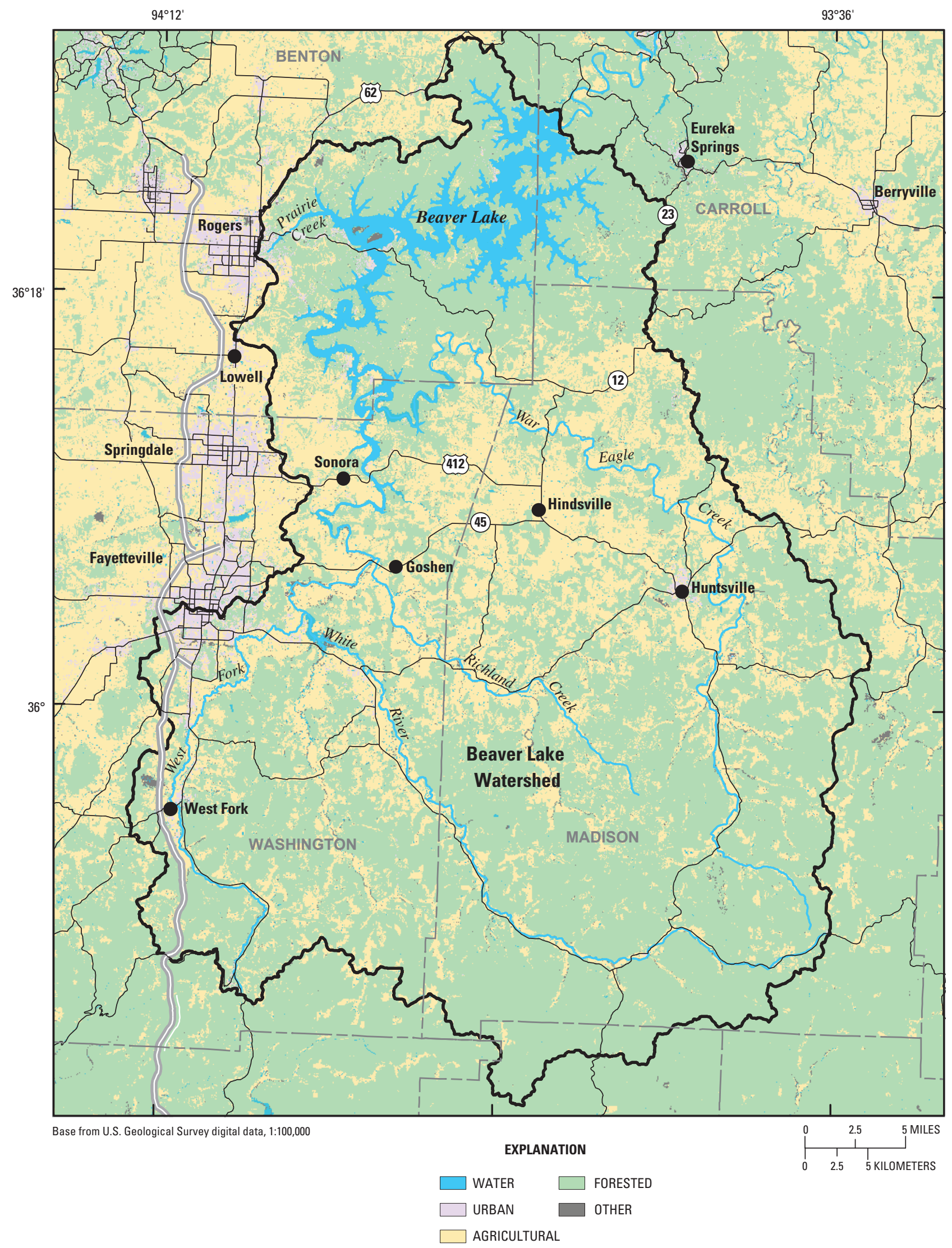

Figure 2. Land use in the Beaver Lake Basin. 

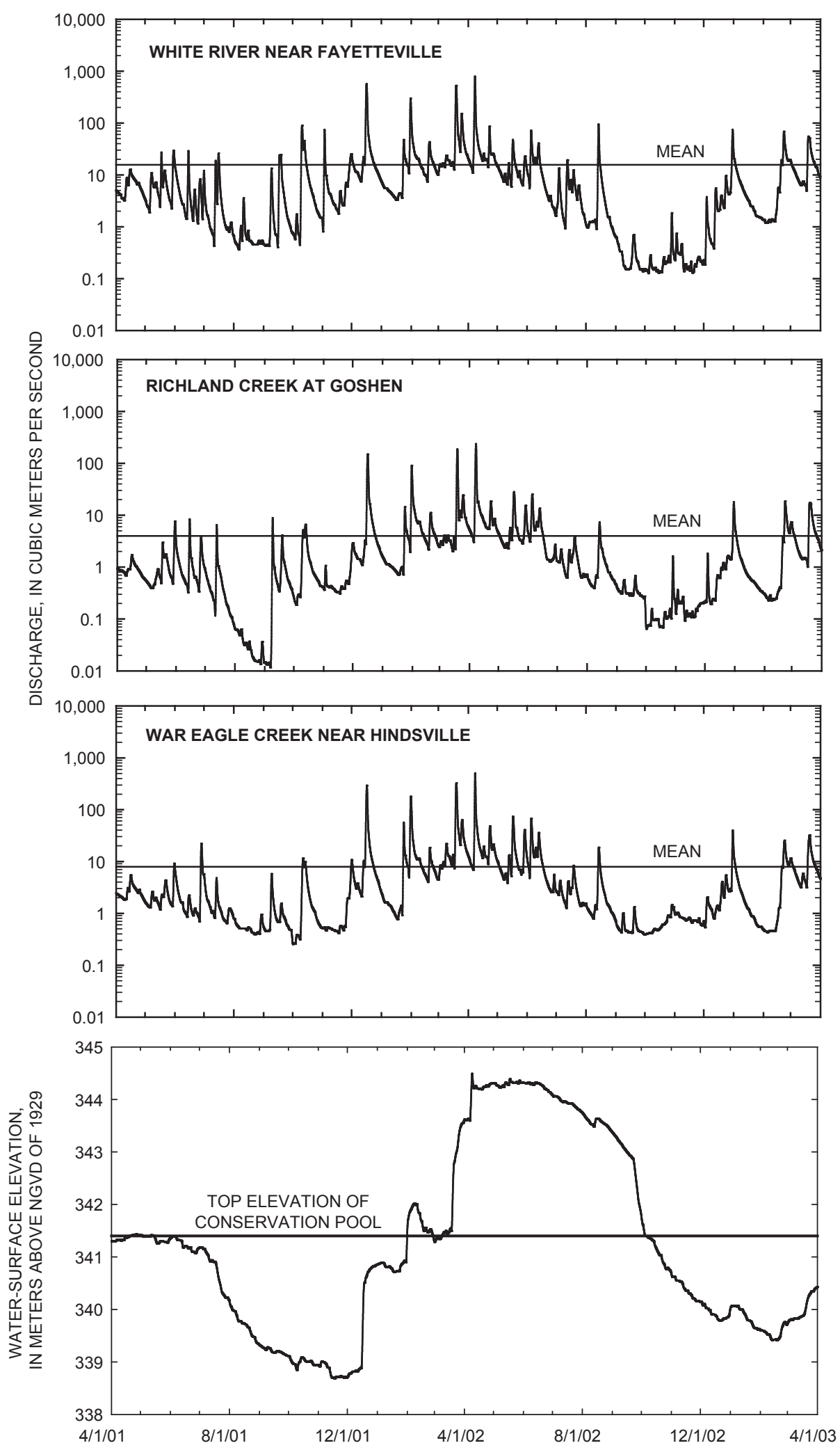

Figure 3. Daily inflow and reservoir water-surface elevation for Beaver Lake, Arkansas, April 2001 to April 2003. 
varying both spatially and temporally (Galloway and Green, 2006). Similar to the results of simulated temperature, differences between simulated and measured values of dissolvedoxygen concentrations were greater in the upstream portion of the reservoir compared to differences in the downstream portion. At the upstream portion of the reservoir at sites L2 and L3, the greatest differences between simulated and measured dissolved oxygen generally occurred in 2002 and the least differences occurred in 2003. Simulated ammonia and total nitrogen concentrations in Beaver Lake compared relatively well with the measured concentrations, and simulated nitrite plus nitrate concentrations generally were lower than the measured data. Simulated values for orthophosphorus were comparable to measured concentrations and simulated total phosphorus concentrations generally were higher than the measured concentrations in Beaver Lake. Simulated chlorophyll $a$ values were similar to measured chlorophyll $a$ both spatially and temporally in Beaver Lake. The greatest differences between simulated and measured chlorophyll $a$ occurred at site L2 with the AME ranging from $4.4 \mathrm{mg} / \mathrm{L}$ (2002) to $6.7 \mathrm{mg} / \mathrm{L}$ (2001) and RMSE ranging from $6.2 \mathrm{mg} / \mathrm{L}$ (2003) to $8.3 \mathrm{mg} / \mathrm{L} \mathrm{(2001).}$

\section{Methods of Evaluating Simulated Changes in Input Water Quality}

Several different applications of the Beaver Lake model were used to evaluate how changes in input nutrient and sediment concentrations affect the water quality in the reservoir. Nutrients (nitrogen and phosphorus) and inorganic suspended solids concentrations were increased and decreased in the main tributaries to Beaver Lake to observe changes in the reservoir water quality from the different scenarios. Several conservative tracer scenarios also were used to observe the fate and transport in Beaver Lake and how the reservoir reacts to a simulated spill. The results are presented in various graphical forms in this section, and digital animations are provided in the attached compact disk.

\section{Nutrient Scenarios}

Forty-eight different nutrient loading scenarios were simulated using the calibrated Beaver Lake model. Nutrient (orthophosphorus, nitrite plus nitrate, and ammonia) concentrations were increased and decreased in the three main inflows to Beaver Lake (White River, Richland Creek, and War Eagle Creek) for the period of April 2001 to April 2003. Orthophosphorus concentrations were decreased by half and increased 2, 5, and 10 times the calibrated daily input concentrations in the three tributaries simultaneously and for each individual tributary. Calibrated daily input nitrite plus nitrate and ammonia concentrations also were decreased by half and increased 2, 5, and 10 times the calibrated concentrations in the three tributaries, simultaneously and independently.
Phosphorus and nitrogen concentrations were increased and decreased independently and simultaneously.

The response of Beaver Lake to changes in the nitrogen and phosphorus concentrations in the tributaries was analyzed by describing the changes in algal biomass (as measured by chlorophyll $a$ concentrations), ammonia, nitrite plus nitrate, total nitrogen, orthophosphorus, and total phosphorus concentrations at four sites in Beaver Lake. The four sites correspond with water-quality monitoring sites in Beaver Lake (fig. 1) that were used for the calibration of the Beaver Lake model (Galloway and Green, 2006). Time-series data from $2 \mathrm{~m}$ below the water surface (epilimnion) and at $2 \mathrm{~m}$ above the reservoir bottom (hypolimnion) were used to examine each scenario result.

\section{Suspended-Solids Scenarios}

Sixteen different suspended-solids scenarios were developed using the calibrated Beaver Lake model. Daily input inorganic suspended solids were decreased by half and increased by 2, 5, and 10 times the input concentrations for the White River, Richland Creek, and War Eagle Creek simultaneously and for each tributary independently.

The response of Beaver Lake to changes in the inorganic suspended-solids concentrations in the tributaries was analyzed by describing the changes in total suspended solids (TSS) at the four established water-quality monitoring sites in Beaver Lake. Time-series data from the epilimnion and hypolimnion were used to examine scenario results over time.

\section{Conservative Tracer Scenarios}

To observe the fate and transport in Beaver Lake and simulate how the reservoir would react to the introduction of a conservative substance or a worst-case spill scenario, a conservative tracer was introduced at several points in the Beaver Lake model under various flow conditions. Because the tracer is conservative, it does not decay or settle in the water column. The tracer was placed at eight locations in the model grid (scenarios 1-8) where a possible spill could occur by adding a tributary input at each of the eight locations (fig. 4) for a total of 16 simulations. A tributary does not add volume to the model grid, but allows for the addition of constituent mass and flow. The tracer was inserted at a concentration of $1.46 \times 10^{9}$ $\mathrm{mg} / \mathrm{L}$ and at a flow rate of $0.19 \mathrm{~m}^{3} / \mathrm{s}$ over a 1 -hour period. The high concentration was used to overcome the dilution effects of the reservoir so substantial changes in concentration could be observed in Beaver Lake. The response of the conservative tracer was evaluated at the locations and depths of the four water-supply intakes in Beaver Lake (fig. 4) using digital animations of tracer concentrations in the main body of the reservoir over time. 


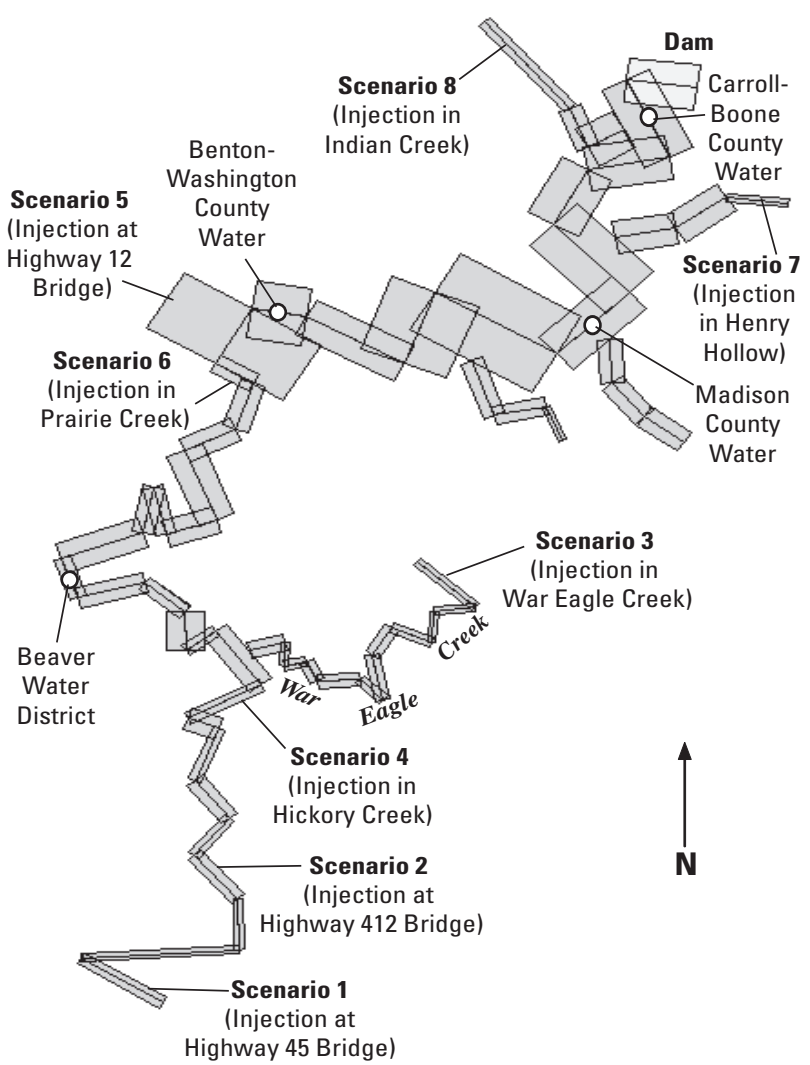

Figure 4. Locations of conservative tracer injection points and water-supply intakes on the Beaver Lake model grid.

\section{Data Analysis}

The Wilcoxon rank sum test (Helsel and Hirsch, 1992) was used to test for differences in selected water-quality constituents between sites and the various scenarios. The Wilcoxon rank sum test is a nonparametric test that determines the probability (p) that the mean of a dataset is similar to the mean of another dataset within a 95 percent confidence interval. For example, a $p$ value less than 0.05 indicates that the mean of one dataset is significantly different than the mean of another.

\section{Evaluation of Simulated Changes in Input Water Quality}

\section{Evaluation of Simulated Changes in Nutrient Loading}

The response of Beaver Lake to changes in the nitrogen and phosphorus loading in the tributaries was analyzed by describing the changes in nitrogen (ammonia, nitrite plus nitrate), and phosphorus (orthophosphorus and total phosphorus) concentrations, and algal biomass using chlorophyll $a$ concentrations. Scenario results were compared to the calibrated model results at four sites in Beaver Lake in the epilimnion and hypolimnion.

\section{Nutrients}

Nutrient (nitrogen and phosphorus) concentrations in Beaver Lake increased proportionally with increases in loads from the three main tributaries (figs. 5-9). An increase of 10 times the calibrated daily input nitrogen and phosphorus in the three main tributaries resulted in daily mean total nitrogen concentrations in the epilimnion that were nearly 4 times greater than the calibration concentrations (table 1) at site L2 and more than 2 times greater than the calibrated concentrations at site L5 (fig. 5). The daily mean nitrite plus nitrate concentrations increased 10 times the calibrated concentration at site L2 and nearly 4 times the calibrated concentrations at site L5 in the epilimnion (fig. 6). Daily mean ammonia concentrations in the epilimnion increased nearly 3 times the calibrated concentrations at sites L2 and L5 (fig. 7). Daily mean concentrations of ammonia in the hypolimnion of site L2 increased nearly 2 times the calibrated concentration and was similar to the calibrated concentration at site L5. When the calibrated daily input concentrations of nitrogen and phosphorus were increased 5 times in the three main tributaries, the resulting daily mean total nitrogen concentrations in the reservoir were increased by more than 2 times the calibrated concentrations in the epilimnion at site L2 and nearly 2 times the calibrated concentrations in the epilimnion at site L5. The daily mean nitrite plus nitrate concentrations increased 5 times the calibrated concentration at site L2 and 3 times the calibrated concentrations at site L5 in the epilimnion (fig. 6). Daily mean ammonia concentrations in the epilimnion increased nearly 2 times the calibrated concentrations at sites L2 and L5 (fig. 7). Daily mean concentrations of ammonia in the hypolimnion of sites L2 and L5 did not increase noticeably.

Increases in daily input nitrogen concentrations in the three main tributaries independently did not cause substantial increases in concentrations of nitrogen in Beaver Lake. The mass of nitrogen entering Beaver Lake from each tributary independently was less because the volume of streamflow for each tributary was less than the three combined.

Total nitrogen concentrations did not increase as much in Beaver Lake when daily input nitrogen was increased independently compared to simultaneous increases of nitrogen and phosphorus (fig. 5). One possible explanation is that when nitrogen is increased independently, some of the nitrogen may settle out of the water column and is lost to the sediment. However, when input nitrogen and phosphorus are increased simultaneously, there is a substantial increase in algal biomass. The greater algal population then is present to uptake the nitrogen, keeping it in the water column as organic nitrogen, resulting in slightly greater total nitrogen concentrations in the water column. 


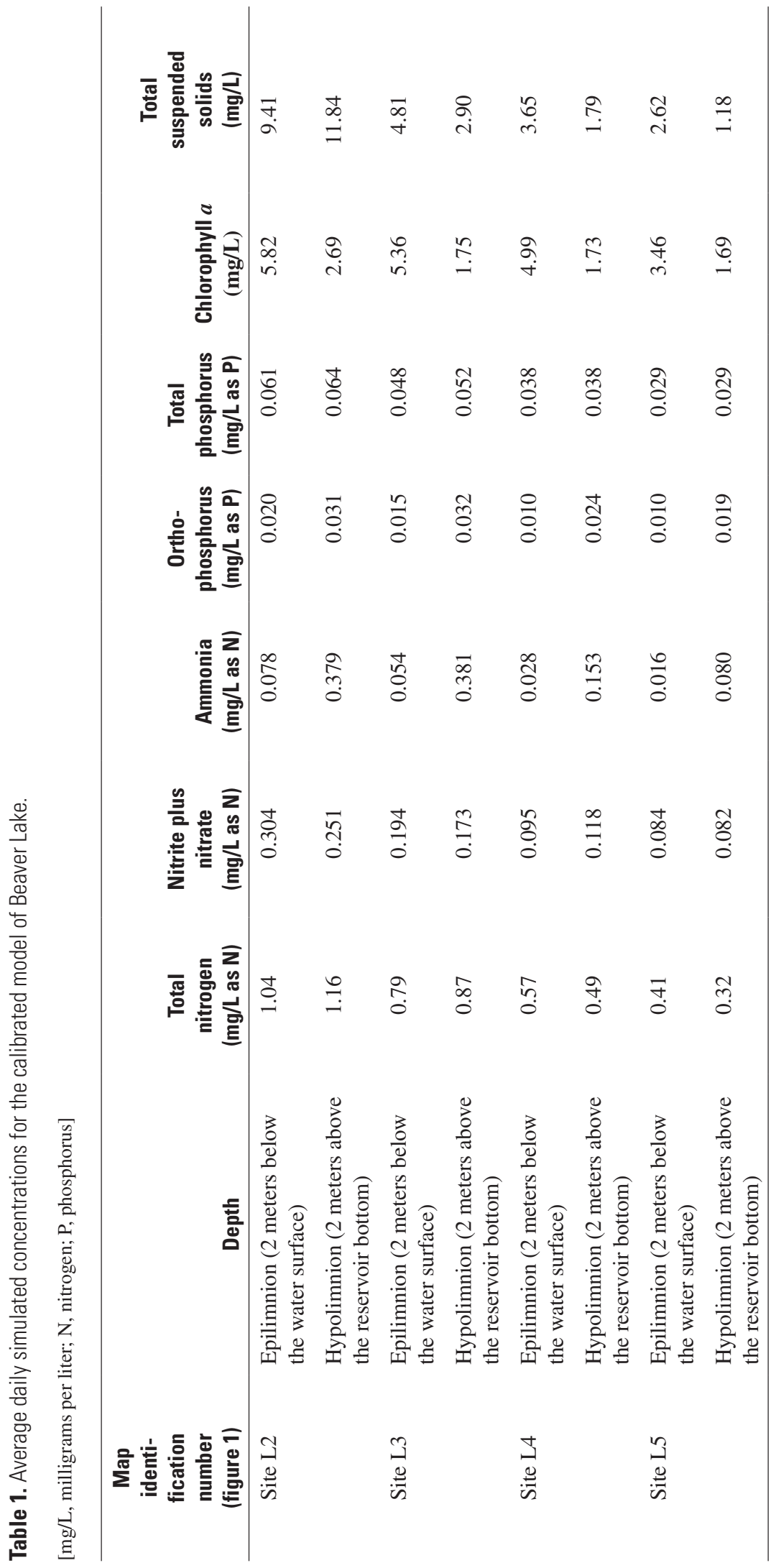




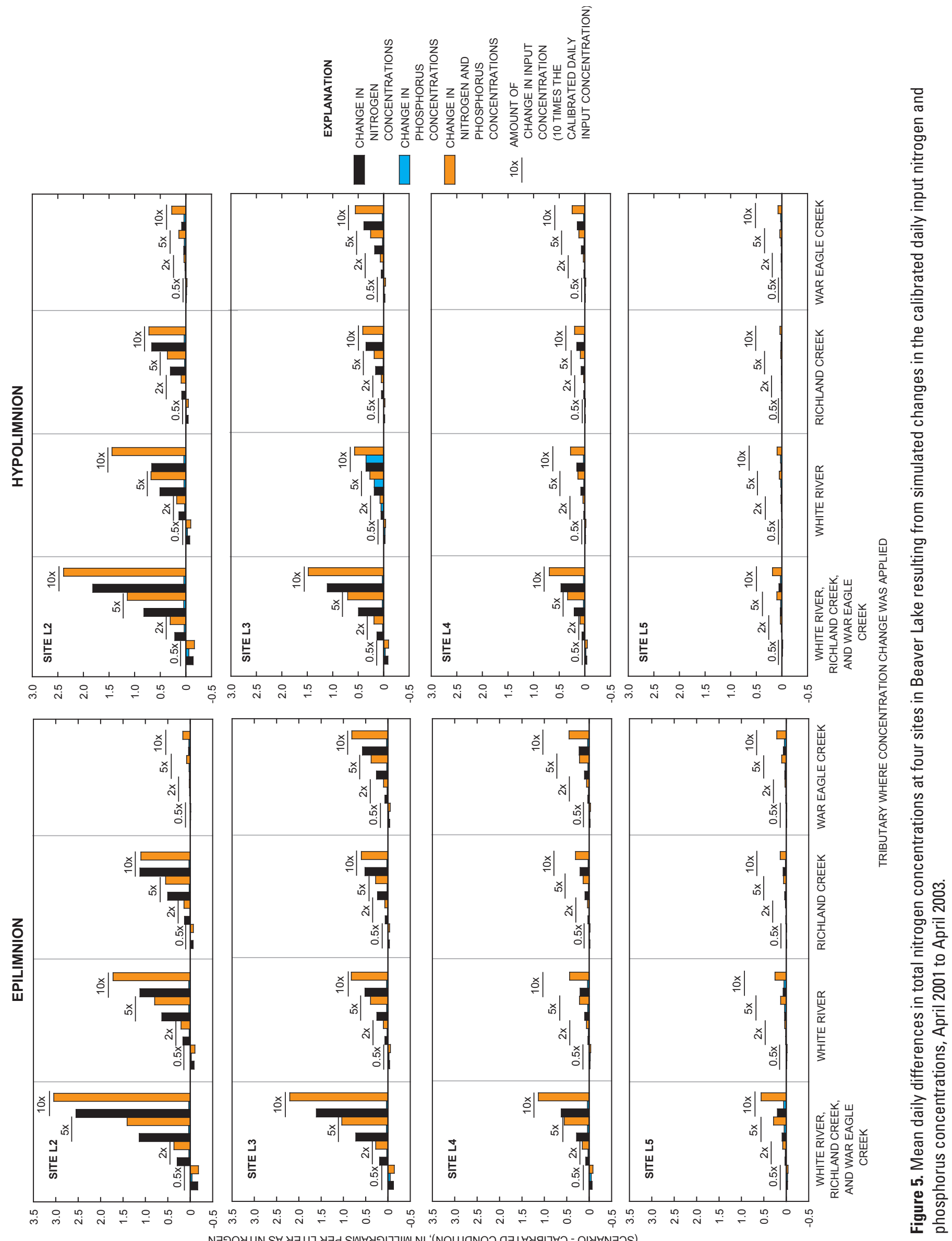




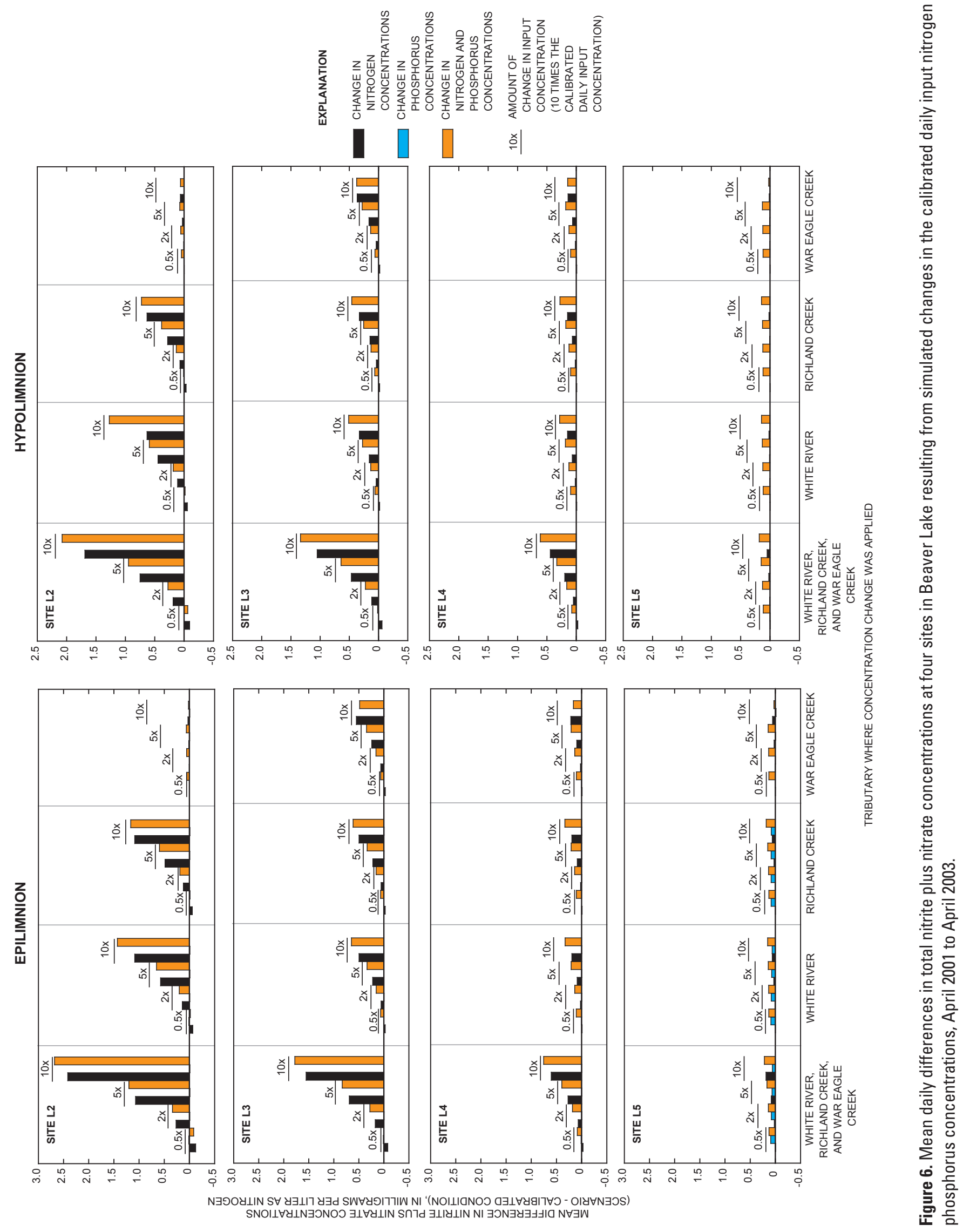




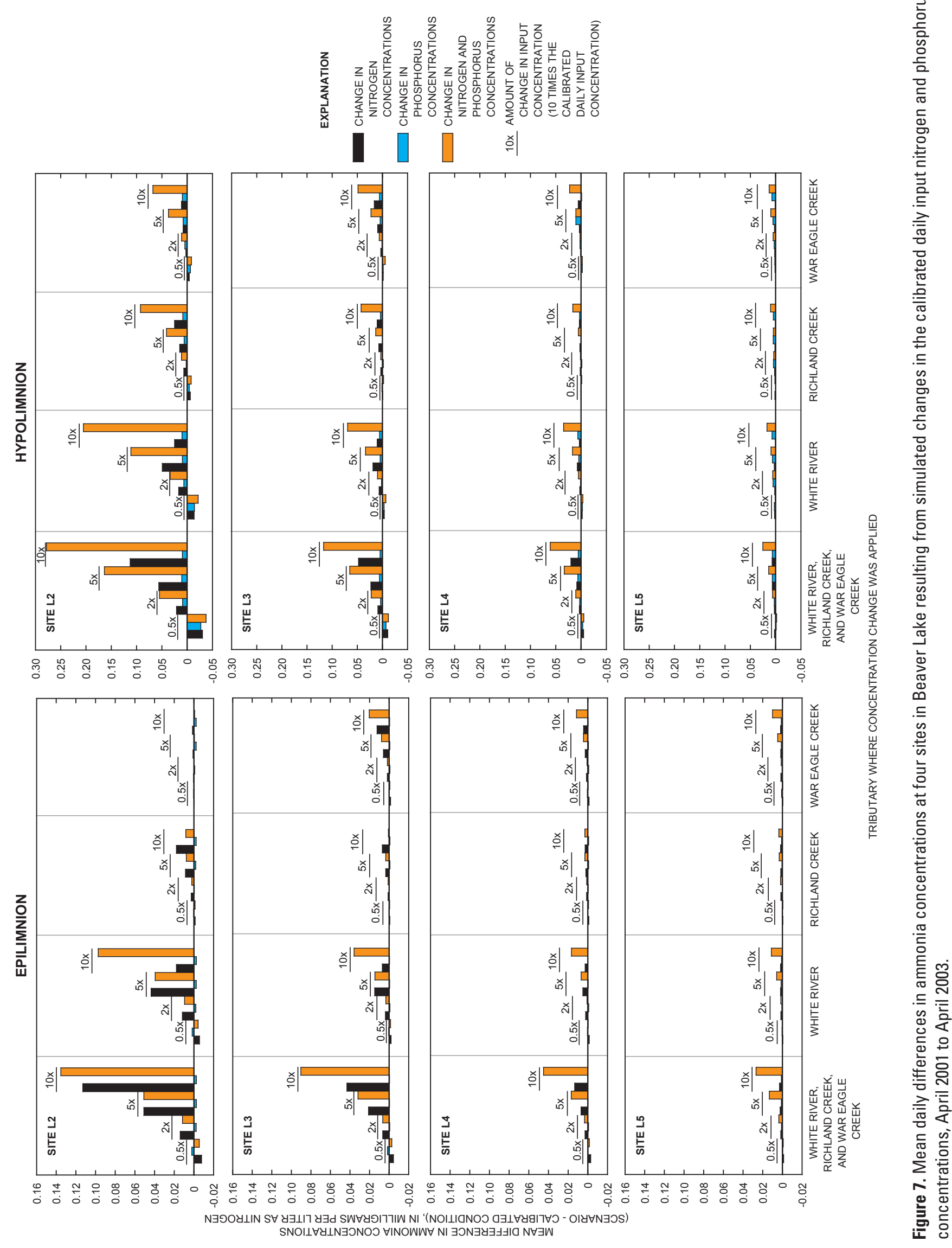




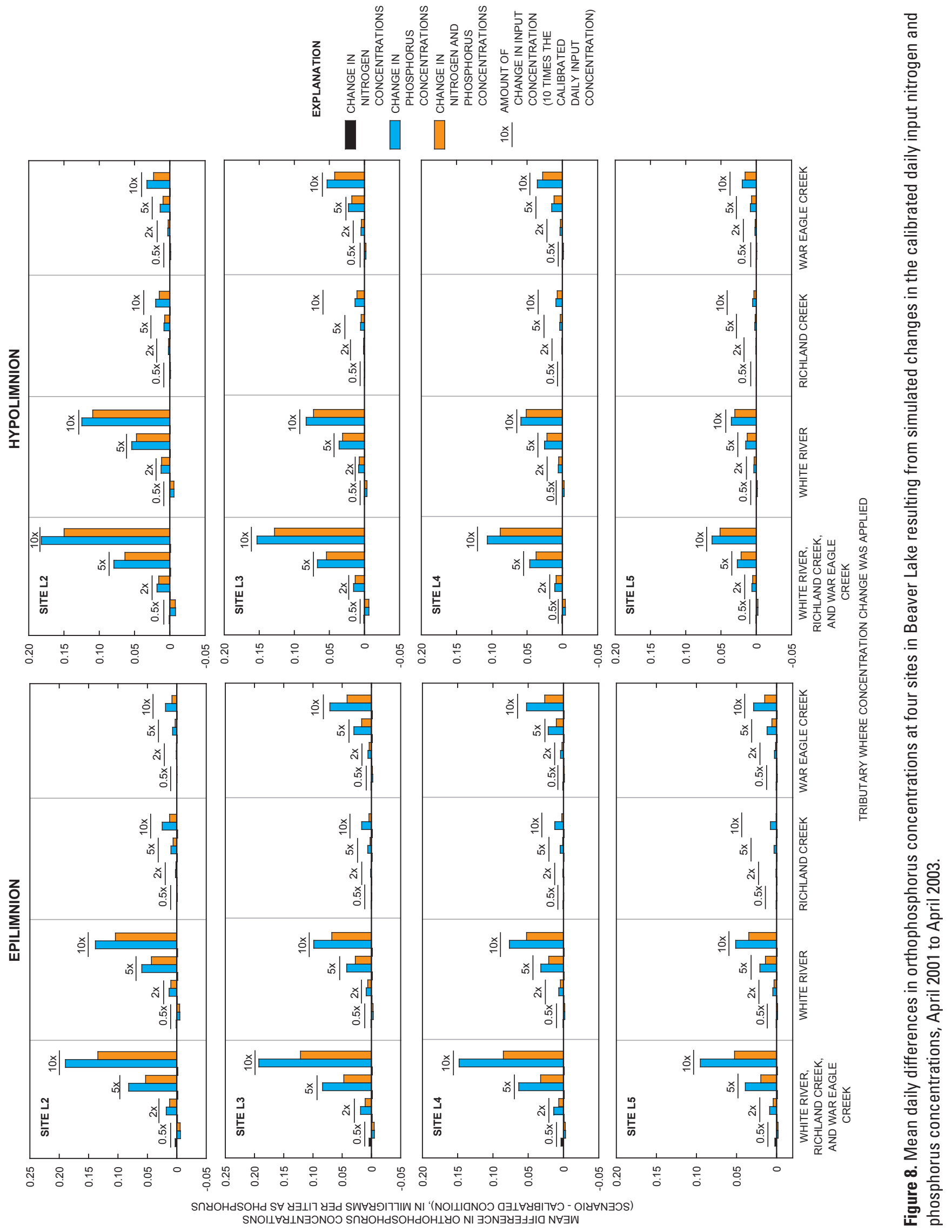




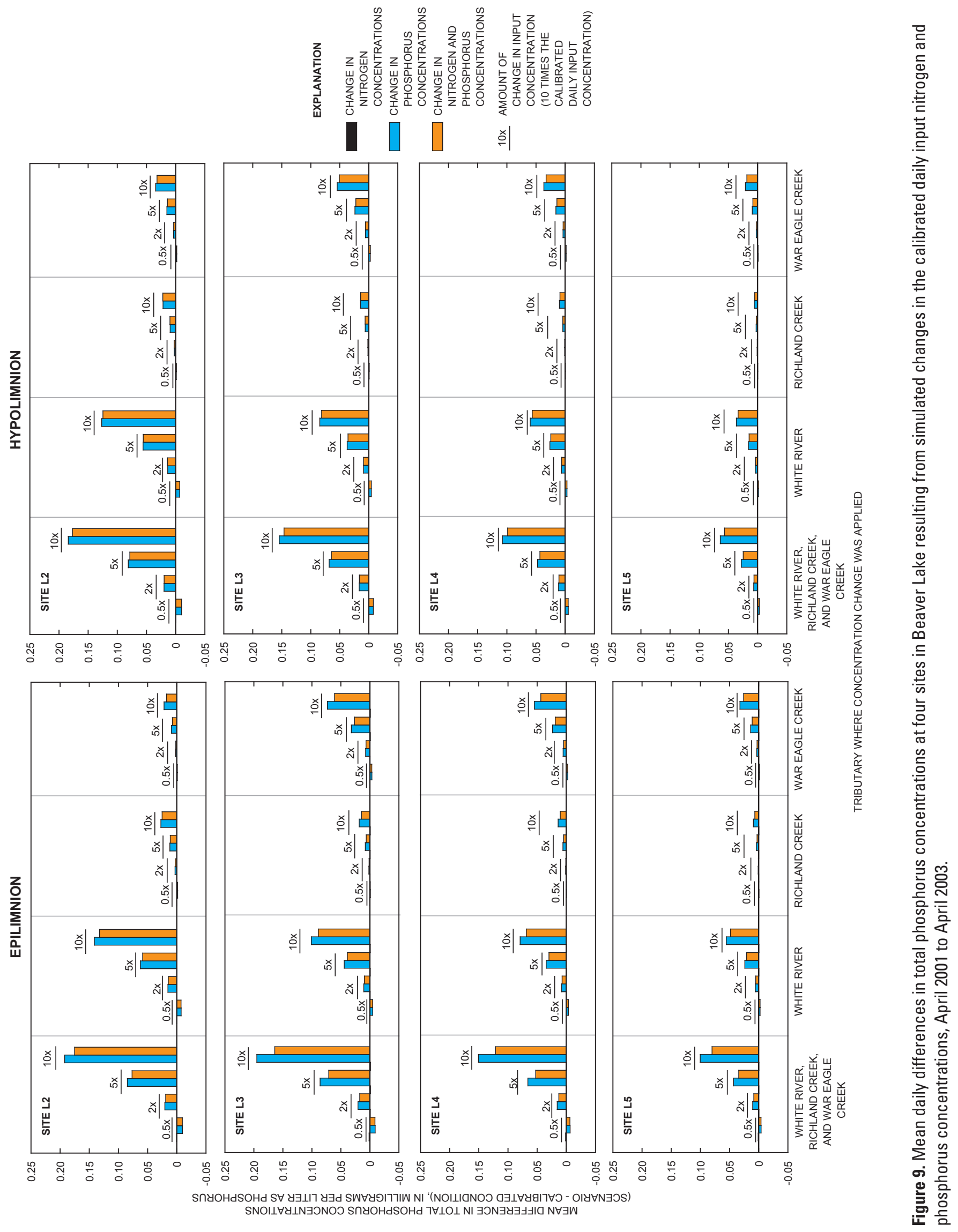


The greatest proportional increase in phosphorus concentrations in the lake occurred in the epilimnion at sites L3 and L4 and the least increase occurred at sites L2 and L5 when calibrated daily input phosphorus concentrations were increased independently from nitrogen (figs. 8 and 9). When orthophosphorus was increased independently from nitrogen in all three tributaries by a factor of 10, daily mean orthophosphorus concentrations in the epilimnion of the reservoir were almost 11 times greater than the calibrated concentrations (table 1) at sites L2 and L5, and 15 times greater in the epilimnion of the reservoir at sites L3 and L4 (fig. 8). Daily mean total phosphorus concentrations were 4 times greater than the calibrated concentrations at sites L2 and L5, and 5 times greater at sites L3 and L4 in the epilimnion (fig. 9). An increase of 5 times the calibrated daily input phosphorus concentrations in all three tributaries resulted in an increase in orthophosphorus to 5 times the calibrated concentrations at sites L2 and L5 and 7 times the calibrated concentrations in the epilimnion at sites L3 and L4 (fig. 8). Total phosphorus increased to more than 2 times the calibrated concentrations at sites L2 and L5 and nearly 3 times the calibrated concentrations at sites L3 and L4 in the epilimnion (fig. 9).

Phosphorus concentrations did not increase as much in Beaver Lake when nitrogen and phosphorus were increased simultaneously compared to when phosphorus was increased independently (fig. 8). For example, when nitrogen and phosphorus were increased by a factor of 10 in all three tributaries simultaneously, orthophosphorus in the epilimnion at site L3 increased $0.121 \mathrm{mg} / \mathrm{L}$ as phosphorus (9 times the calibrated concentration) and total phosphorus increased $0.164 \mathrm{mg} / \mathrm{L}$ as phosphorus (more than 4 times the calibrated condition). In comparison, when phosphorus was increased independently by a factor of 10 in all three tributaries, orthophosphorus concentrations increased by $0.192 \mathrm{mg} / \mathrm{L}$ as phosphorus (nearly 14 times the calibrated condition) and total phosphorus increased by $0.195 \mathrm{mg} / \mathrm{L}$ as phosphorus ( 5 times the calibrated concentrations) in the epilimnion at site L3 (figs. 8 and 9). When phosphorus was increased independently in the three tributaries, algal production may have become limited by nitrogen, allowing orthophosphorus to remain in the water column. When nitrogen and phosphorus were increased simultaneously, algal production was not limited by nitrogen or phosphorus, algal production increased substantially, and more orthophosphorus was used by the algae, removing more from the water column.

\section{Algal Biomass}

The greatest simulated increase in algal biomass (represented as chlorophyll $a$ ) in Beaver Lake occurred when nitrogen and phosphorus were increased simultaneously in the three main tributaries (figs. 10 and 11). In general, because algae need nitrogen and phosphorus to grow (in addition to light and other nutrient constituents), if the availability of any one of the nutrients in the water column were limited for uptake by the different algal species, the growth of the algae species will be limited by the least available nutrient (Reynolds, 1984). Beaver Lake generally is considered to be phosphorus limited because of the greater availability of nitrogen (higher concentrations) and the relatively limited availability of phosphorus (lower concentrations). As a result, when only additional nitrogen was introduced into Beaver Lake, algal biomass did not increase significantly ( $p>0.05)$ in most of the reservoir (figs. 10 and 12) because algal growth remained limited by the less available phosphorus in the water column. However, when additional phosphorus was introduced into Beaver Lake independently from nitrogen, algal biomass increased significantly $(\mathrm{p}<0.05)$ compared to the calibrated concentrations (table 1). When additions of nitrogen and phosphorus were introduced simultaneously, algal biomass was much greater than when nitrogen or phosphorus were added independently (figs. 10 and 13).

On average, the chlorophyll $a$ values increased less than $1 \mu \mathrm{g} / \mathrm{L}$ when concentrations of nitrogen or phosphorus were increased independently by a factor of 10 at all three tributaries (fig. 10). The maximum increase in chlorophyll $a$ concentrations in the epilimnion at site L3 in Beaver Lake was less than $4 \mu \mathrm{g} / \mathrm{L}$ when nitrogen or phosphorus was increased independently by a factor of 10 at all three tributaries (figs. 12 and 13), which was within the error of the calibrated model. In comparison, when nitrogen and phosphorus were increased simultaneously by a factor of 10 for all three tributaries, the chlorophyll $a$ concentration increased by about $10 \mu \mathrm{g} / \mathrm{L}$ on average (fig. 10), with a maximum increase of about 57 $\mu \mathrm{g} / \mathrm{L}$ in the epilimnion at site L3 in Beaver Lake (fig. 11). A significant increase $(\mathrm{p}<0.05)$ in chlorophyll $a$ concentrations in Beaver Lake also occurred when phosphorus was increased independently and when nitrogen and phosphorus were increased simultaneously only in the White River, although the differences were within the error of the calibrated model. Increases in nitrogen and phosphorus by a factor of 5 and 10 in Richland and War Eagle Creeks also resulted in significant increases $(\mathrm{p}<0.05)$ in chlorophyll $a$ concentrations in the reservoir. Although the increase in chlorophyll $a$ concentrations were statistically significant, the differences were within the error of the calibrated model (figs. 10 and 11), which adds a degree of uncertainty to the analysis of the results.

The horizontal and vertical distribution of algal biomass in Beaver Lake also was affected by changes in daily input nitrogen and phosphorus concentrations. When daily input nitrogen and phosphorus concentrations were increased to 10 times the calibrated condition, simulated chlorophyll $a$ concentrations increased substantially across the reservoir to depths of up to $12 \mathrm{~m}$ (fig. 14) in May of 2002. In 2001, the largest increase in chlorophyll $a$ mainly occurred in the upstream portion of the reservoir in late spring. In comparison, when nitrogen and phosphorus were increased independently, chlorophyll $a$ concentrations increased mostly in the upstream portion of the reservoir, although substantial increases in concentrations did not occur overall, presumably because of nutrient limitation of the algae. 


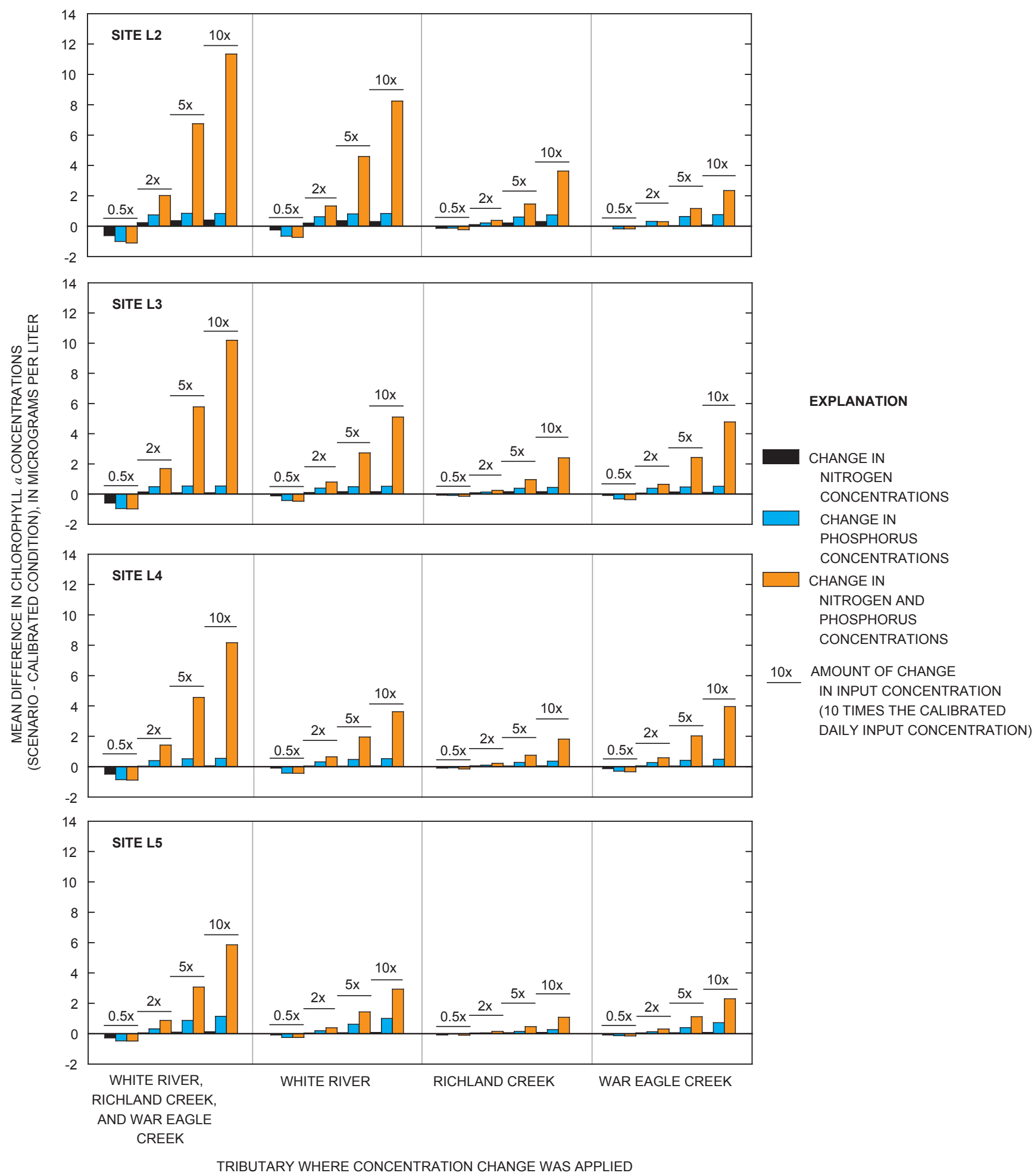

Figure 10. Mean daily differences in simulated chlorophyll $a$ concentrations at four sites in Beaver Lake resulting from simulated changes in the calibrated daily input nitrogen and phosphorus concentrations, April 2001 to April 2003. 


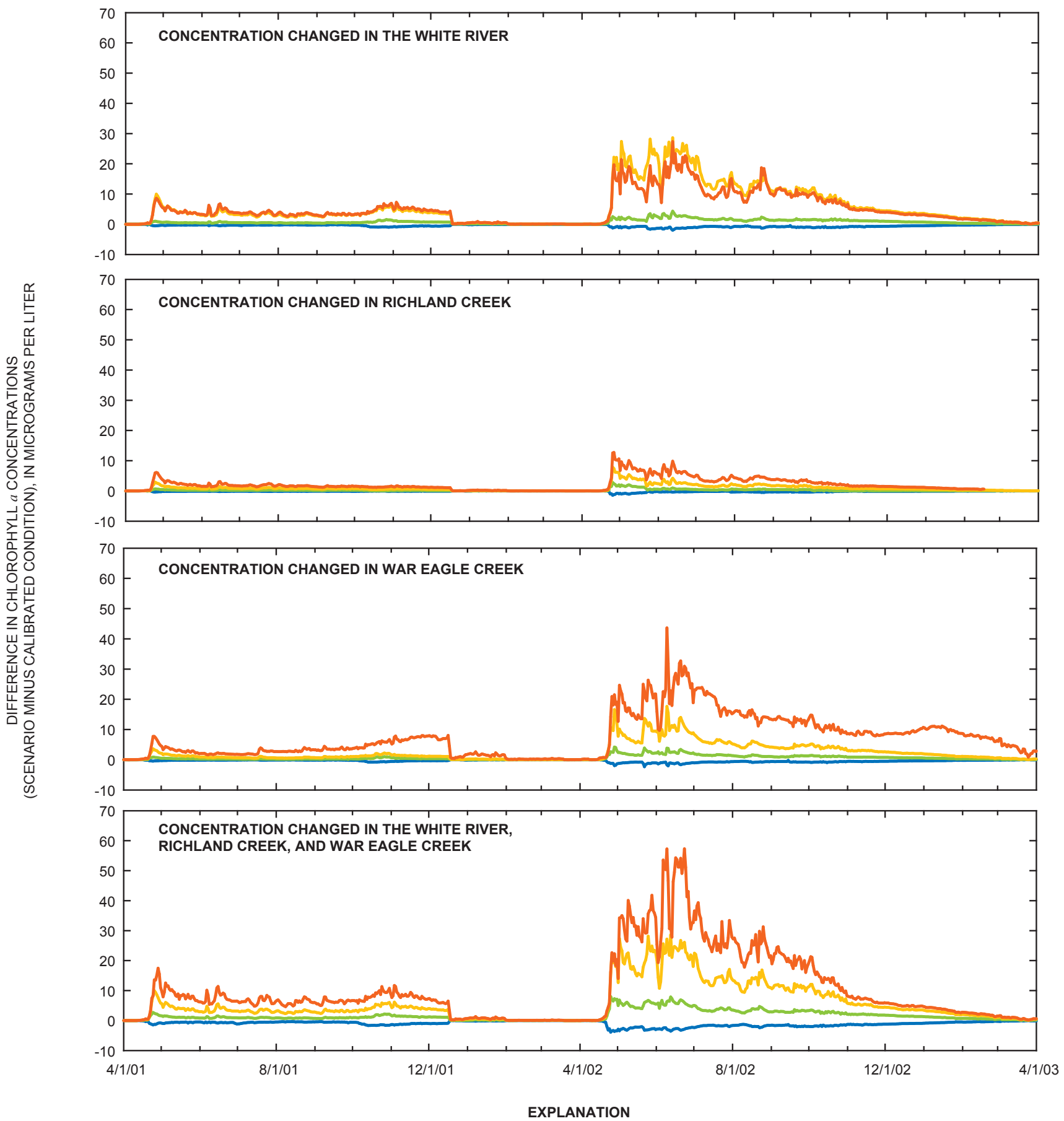

Figure 11. Time series of daily differences in simulated chlorophyll $a$ values in the epilimnion at Beaver Lake at Lowell, Arkansas (site L3), resulting from simulated changes in the calibrated daily input nitrogen and phosphorus concentrations, April 2001 to April 2003. 


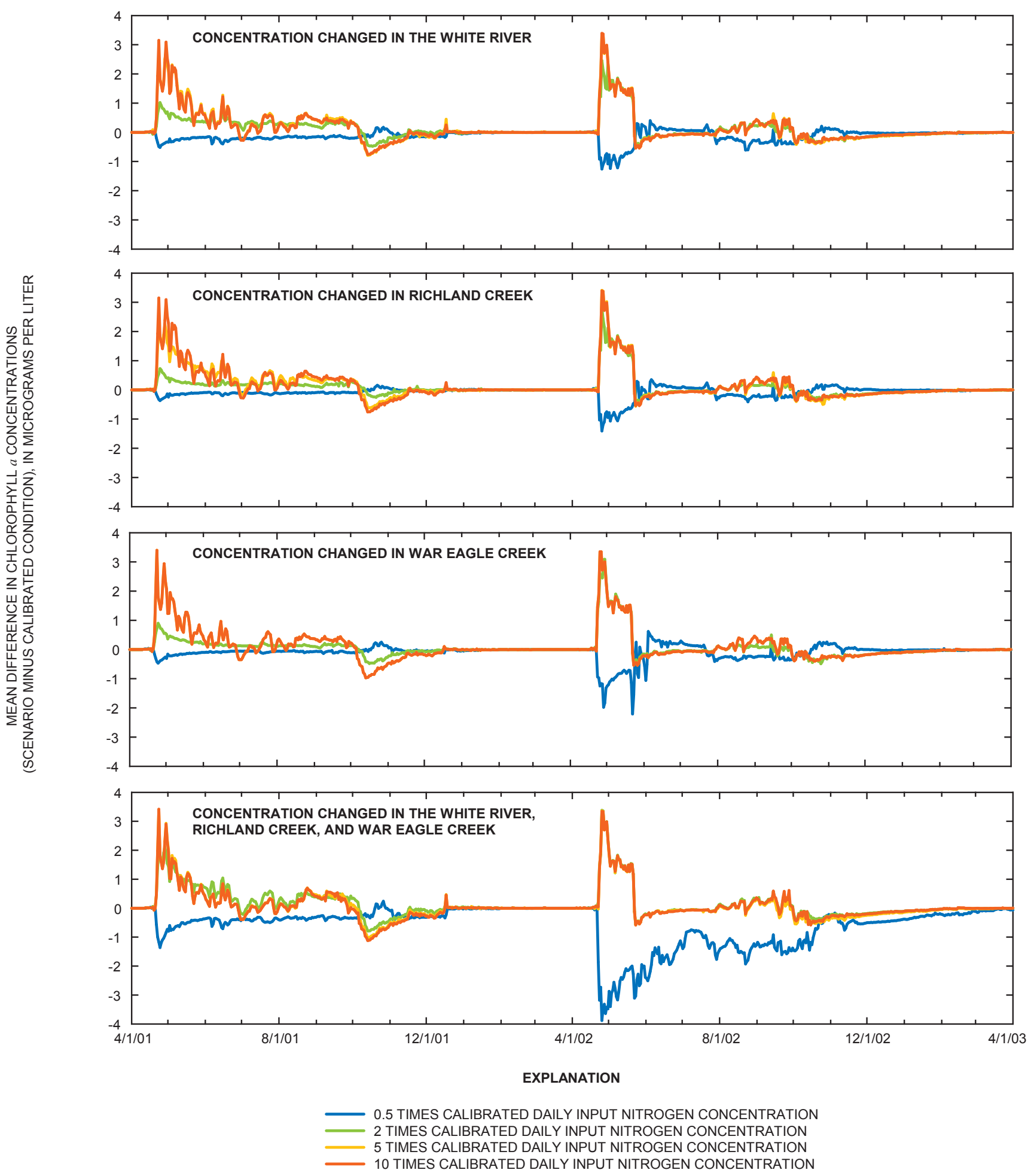

Figure 12. Time series of daily differences in simulated chlorophyll $a$ values in the epilimnion at Beaver Lake at Lowell, Arkansas (site L3), resulting from simulated changes in the calibrated daily input nitrogen concentrations, April 2001 to April 2003. 


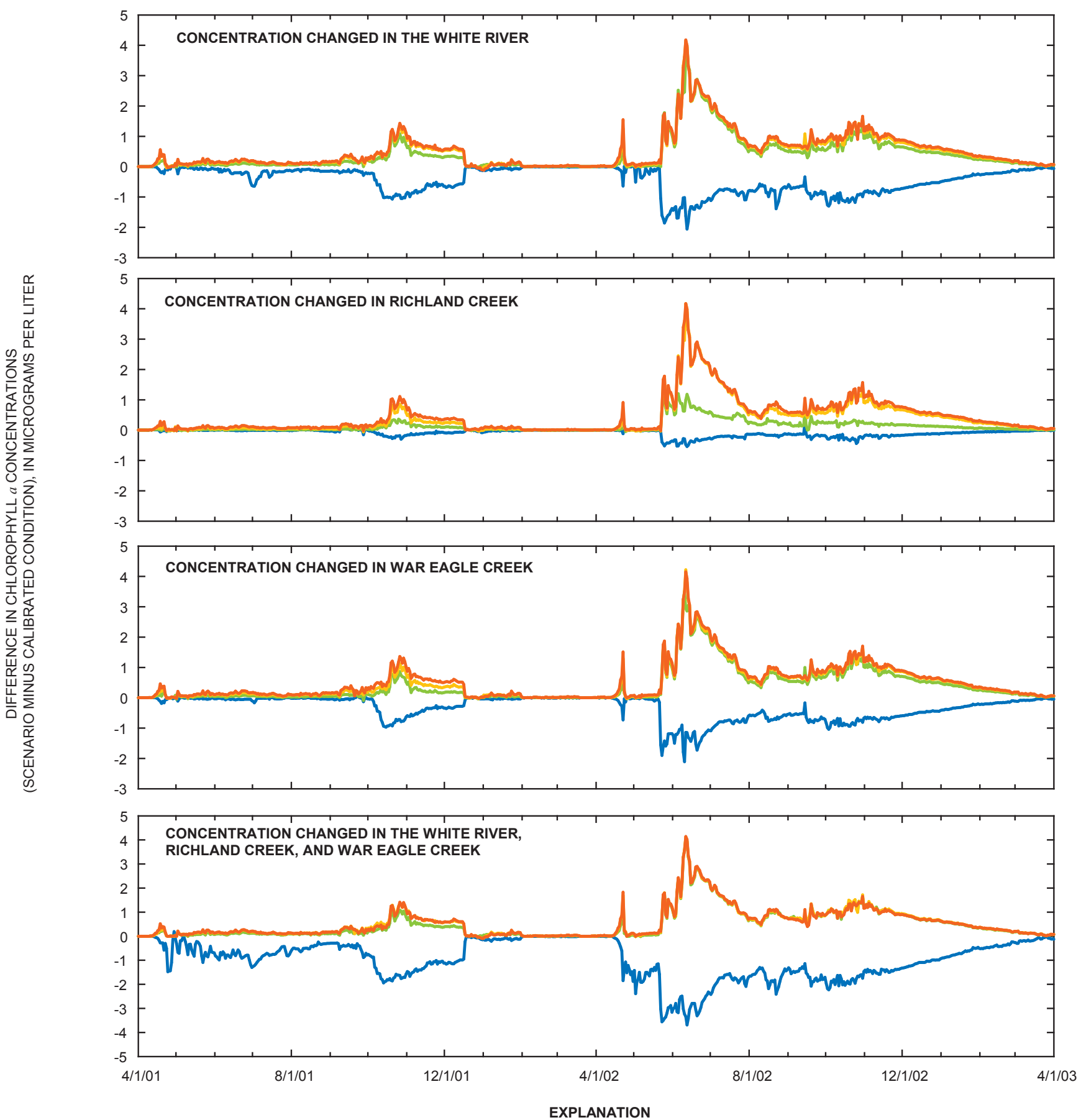

0.5 TIMES CALIBRATED DAILY INPUT PHOSPHORUS CONCENTRATION
2 TIMES CALIBRATED DAILY INPUT PHOSPHORUS CONCENTRATION

5 TIMES CALIBRATED DAILY INPUT PHOSPHORUS CONCENTRATION

10 TIMES CALIBRATED DAILY INPUT PHOSPHORUS CONCENTRATION

Figure 13. Time series of daily differences in simulated chlorophyll $a$ values in the epilimnion at Beaver Lake at Lowell, Arkansas (site L3), resulting from simulated changes in the calibrated daily input phosphorus concentrations, April 2001 to April 2003. 

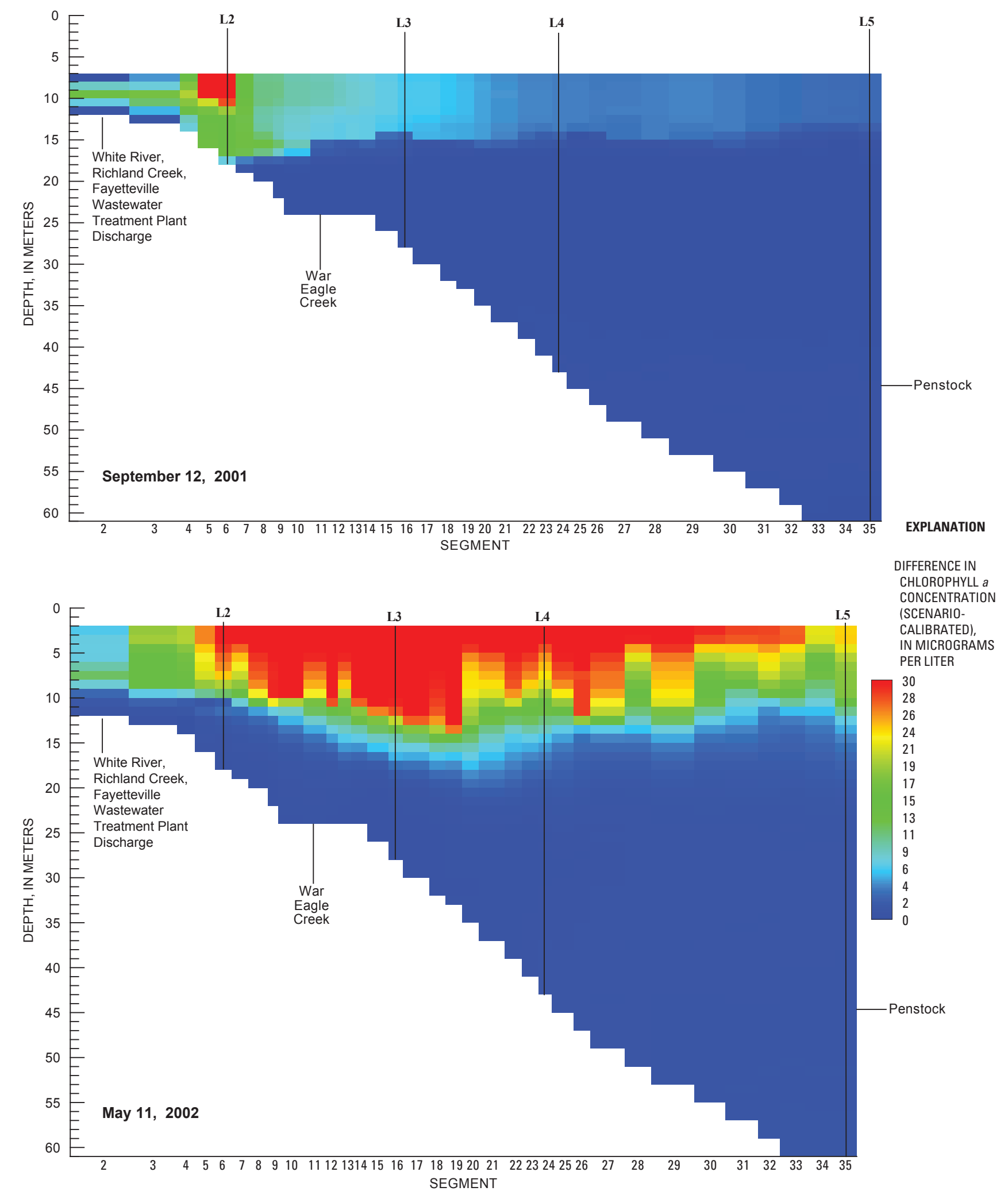

Figure 14. Mean differences in simulated chlorophyll $a$ concentrations in the main branch of the Beaver Lake model resulting from a simulation of 10 times the calibrated daily input nitrogen and phosphorus concentrations on September 12, 2001 and May 11, 2002. 
Changes in algal biomass with changes in input nitrogen and phosphorus were variable through time in the Beaver Lake model from April 2001 to April 2003. When calibrated daily input nitrogen and phosphorus concentrations were increased simultaneously for the three main tributaries, the increase in chlorophyll $a$ concentrations was the greatest in the late spring and summer of 2002 (fig. 11). Increases in chlorophyll $a$ concentrations probably were not as great in late spring and summer of 2001 because of the hydrologic conditions (fig. 3). April through November 2001 was a relatively dry period with daily mean streamflows of 5.30, 0.90, and $1.80 \mathrm{~m}^{3} / \mathrm{s}$, for the White River, Richland Creek, and War Eagle Creek, respectively, which would mean that less mass (load) of nitrogen and phosphorus was delivered to Beaver Lake than in the subsequent months. From November 2001 through April 2002 the daily mean streamflows for the White River, Richland Creek, and War Eagle Creek were 28.9, 7.05, and $15.4 \mathrm{~m}^{3} / \mathrm{s}$, respectively, which would mean a greater nutrient mass was transported into the reservoir. When water temperatures and water clarity were ideal for algal growth in late spring 2002, a relatively high amount of nutrients were readily available for algal uptake, resulting in significantly $(\mathrm{p}<0.05)$ greater algal growth and higher chlorophyll $a$ concentrations from May through November 2002 than in April through November 2001 (fig. 11).

Other factors that affect the growth of algae, other than the nutrient dynamics, include light availability in the water column, water temperature, and the composition of the phytoplankton community of the lake, because different species of phytoplankton utilize different nutrients at different rates (Harris, 1986). Although the model does account for light attenuation in the water column and the effects of water temperature on growth, it does not fully capture the complexities of the phytoplankton community (Galloway and Green, 2006).

\section{Evaluation of Simulated Changes in Suspended Solids Loading}

Changes in calibrated daily input inorganic suspended solids (suspended sediment) were examined because of the effect they may have on water clarity in Beaver Lake. In addition to inorganic suspended solids, water clarity also is affected by the organic material and color in the water column. Water clarity in the reservoir was determined by measuring turbidity and Secchi depth (Galloway and Green, 2006). However, turbidity and Secchi depth are not simulated in CEQUAL-W2; although suspended-solids concentration is simulated. The CE-QUAL-W2 model of Beaver Lake does account for organic material in the water column, but not color effects. The analysis of total suspended solids (TSS) also is limited because although inorganic suspended solids were included in the calibrated model to simulate their effects on light extinction in Beaver Lake, they were not compared and adjusted to measured values in the reservoir. The calibrated daily input inorganic suspended-solids concentrations (suspended sedi- ment) in the three main tributaries were decreased by half and increased 2, 5 and 10 times the concentrations used in the calibrated Beaver Lake model for all of the tributaries simultaneously and independently. Although the changes may not completely account for the changes in water clarity because of the limits of the model, the changes in TSS (inorganic and organic material) may provide information on the relative change in water clarity in Beaver Lake.

TSS concentrations in Beaver Lake increased proportionally to increases in the input inorganic suspended-solids concentration. The increase in TSS was greatest in the hypolimnion at the upstream end of Beaver Lake, and negligible changes were observed at the downstream end of the reservoir for all of the scenarios (fig. 15). An increase of 10 times the calibrated daily input concentration of inorganic suspended solids in all three tributaries resulted in an increase in daily mean TSS concentration of $39.1 \mathrm{mg} / \mathrm{L}$ in the epilimnion (more than 5 times the calibrated condition) and $107 \mathrm{mg} / \mathrm{L}$ in the hypolimnion (more than 10 times the calibrated condition) at site L2 and $2.07 \mathrm{mg} / \mathrm{L}$ in the epilimnion (similar to the calibrated condition) and $30.7 \mathrm{mg} / \mathrm{L}$ in the hypolimnion (nearly 12 times the calibrated condition) at site L3 (fig.15). An increase of 10 times the inorganic suspended solids in the White River independently resulted in an increase of daily mean TSS concentrations of $36.3 \mathrm{mg} / \mathrm{L}$ in the epilimnion (nearly 5 times the calibrated condition) and $106 \mathrm{mg} / \mathrm{L}$ in the hypolimnion (10 times the calibrated condition) at site $\mathrm{L} 2$ and $0.96 \mathrm{mg} / \mathrm{L}$ in the epilimnion (similar to the calibrated condition) and $30.5 \mathrm{mg} / \mathrm{L}$ in the hypolimnion (more than 11 times the calibrated condition) at site L3. An increase of 5 times the calibrated daily input concentration of inorganic suspended solids in all three tributaries resulted in an increase of more than 3 times the daily mean concentration of the calibrated condition of TSS (table 1) in the epilimnion and 5 times the calibrated concentrations in the hypolimnion at site L2. Increases in the inorganic suspended solids in Richland and War Eagle Creeks did not result in substantial increases in the reservoir. The increase in the daily mean TSS concentration at sites L4 and L5 in both the epilimnion and hypolimnion was less than $1 \mathrm{mg} / \mathrm{L}$ when the inorganic suspended-solids concentrations were increased by a factor of 10 in the three main tributaries, indicating that most of the sediment settles out of the water column in the upstream portion of the reservoir (figs. 15 and 16).

TSS concentrations demonstrated a greater increase in the hypolimnion because of how the inflow is distributed in the water column of the reservoir according to density. The density of the inflow water generally would be greater because the inflow water in the spring, when most of the high-flow events occur, has lower temperatures compared to the epilimnion of the lake, and because the inflow water has a greater mass of suspended sediment compared to the mass of suspended sediment in the reservoir (fig. 16).

The increase in TSS in the reservoir with increases in input inorganic suspended solids could have a substantial effect on the water clarity in the upstream end of Beaver Lake. Measured turbidity in the epilimnion in Beaver Lake had mean 


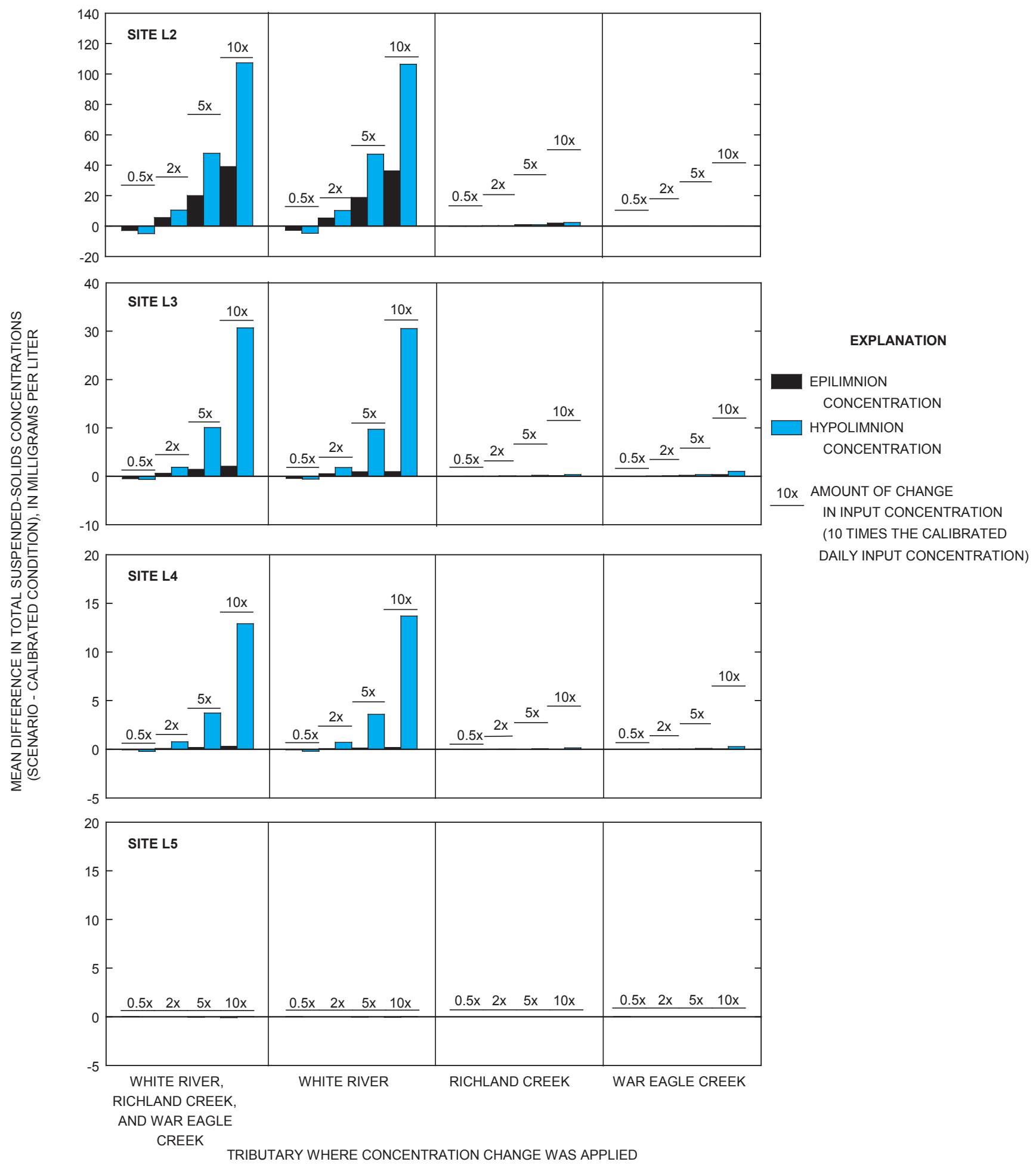

Figure 15. Mean daily differences in total suspended-solids concentrations at four sites in Beaver Lake resulting from simulated changes in daily input inorganic suspended-solids concentrations, April 2001 to April 2003. 


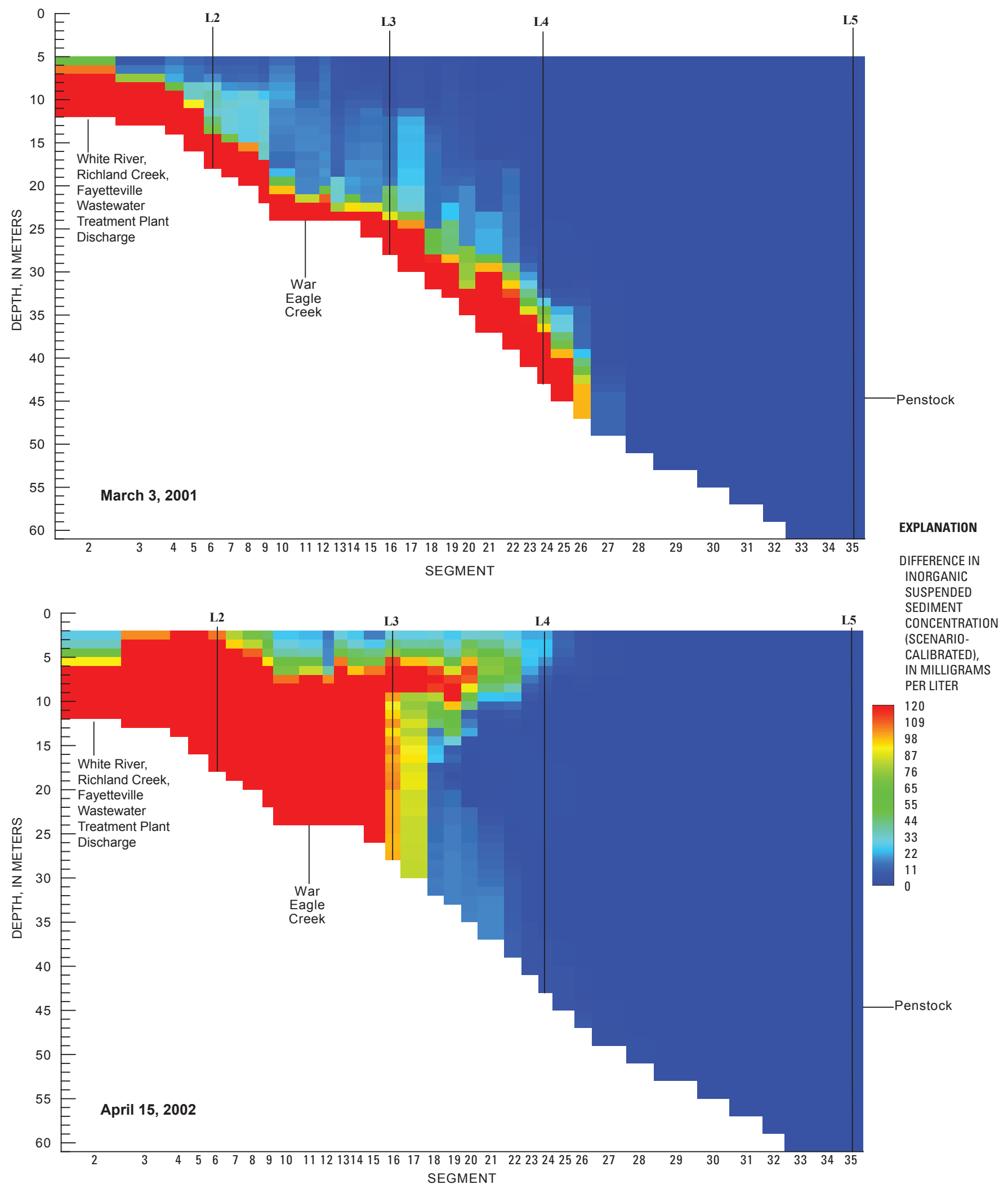

Figure 16. Mean differences in simulated inorganic suspended-solids concentrations in the main branch of the Beaver Lake model resulting from a simulation of 10 times the daily input inorganic suspended-solids concentrations on March 3, 200l and April 15, 2002. 


\section{Application of a Two-Dimensional Reservoir Water-Quality Model of Beaver Lake, Arkansas, for the Evaluation of Simulated Changes in Input Water Quality, 2001-2003}

values of 11.4 nephlometric turbidity units (NTUs) at site L2, 7.9 NTU at site L3, 3.2 NTU at site L4, and 0.6 NTU at site L5 from April 2001 to April 2003 (Porter and others, 2002; Brossett and Evans, 2003; Evans and others, 2004). TSS data were not collected during this time to correlate with turbidity data, but if data had been collected, TSS probably would follow similar changes as turbidity. When the input inorganic suspended solids were increased 10 times the calibrated input concentrations in the three tributaries for the Beaver Lake model, daily mean TSS concentration increased 5 times the calibrated condition at site L2 in the epilimnion. Assuming that turbidity would increase the same magnitude, the mean turbidity would increase from 11.4 NTU to approximately 57 NTU in the epilimnion at the upstream end. Measured turbidity in the hypolimnion in Beaver Lake had mean values of 33.4 NTU at site L2, 28.0 NTU at site L3, 11.4 NTU at site L4, and 1.5 NTU at site L5 from April 2001 to April 2003 (Porter and others, 2002; Brossett and Evans, 2003; Evans and others, 2004). When the input inorganic suspended solids were increased 10 times the calibrated input concentrations in the three tributaries for the Beaver Lake model, daily mean TSS concentration in the hypolimnion increased 10 times the calibrated condition at site L2 and 11.6 times the calibrated conditions at site L3. If turbidity increased at the same rate as TSS, the turbidity in the hypolimnion would increase to approximately 334 NTU at site L2 and 325 NTU at site L3. The current standard for turbidity on Beaver Lake during normal stage conditions is 25 NTU (Arkansas Department of Environmental Quality, 2006).

\section{Evaluation of Simulated Conservative Tracers}

To observe the fate and transport and how the reservoir would react to a simulated spill at various locations in Beaver Lake (table 2), a high concentration of conservative tracer was introduced into the model for relatively short periods of time (1 hour) at eight locations (eight scenarios) in the reservoir (fig. 4) during high-flow (March 17, 2002) and low-flow (August 7, 2001) conditions for a total of 16 simulations (table 2). Tracer concentrations were monitored through time at the locations and depths of the four water-supply intakes located in Beaver Lake (fig. 4). Digital animations of all the scenarios are provided in the attached compact disk.

Concentrations of the conservative tracers at the four water-supply intakes varied substantially between injection locations and flow conditions. The Beaver Water District intake had the highest concentrations when the tracers were placed upstream from the intake in Beaver Lake at Highway 45 (scenario 1), Highway 412 (scenario 2), War Eagle Creek (scenario 3), and Hickory Creek (scenario 4) during high-flow conditions (fig. 17 and table 2). The Hickory Creek embayment is located adjacent to the location of the intake, and injection at the location resulted in the highest concentrations at the Beaver Water District (2,664 mg/L) during high-flow conditions (table 2). Scenarios 1, 2, and 3 had peak concen- trations of $859,1,087$, and $897 \mathrm{mg} / \mathrm{L}$, respectively, during high-flow conditions. In comparison, tracer injections during low-flow conditions yielded peak concentrations of 762, 798, 684 , and $1,006 \mathrm{mg} / \mathrm{L}$ at the intake for scenarios $1-4$, respectively (fig. 18 and table 2). The highest concentrations at the Benton-Washington County Water intake occurred when tracer was placed at the Highway 12 bridge (scenario 5) and in Prairie Creek (scenario 6) during high-flow conditions. The peak concentration for scenario 5 was $611 \mathrm{mg} / \mathrm{L}$ when tracer was injected during high-flow conditions and $165 \mathrm{mg} / \mathrm{L}$ when tracer was injected during low-flow conditions. For scenario 6 , the peak concentration at the intake was $269 \mathrm{mg} / \mathrm{L}$ during high-flow conditions and $158 \mathrm{mg} / \mathrm{L}$ during low-flow conditions. The Madison County Water intake had the highest peak tracer concentrations when tracer was injected in Henry Hollow (scenario 7) at high-flow and low-flow conditions, and when tracer was injected in Indian Creek (scenario 8) during low-flow conditions (figs. 17 and 18). The peak tracer concentration for scenario 7 during high-flow conditions was 179 $\mathrm{mg} / \mathrm{L}$ and during low-flow conditions the peak concentration was $180 \mathrm{mg} / \mathrm{L}$. The peak concentration for scenario 8 during low-flow conditions was $217 \mathrm{mg} / \mathrm{L}$ (table 2, fig. 17). The Carroll-Boone County Water intake experienced the highest peak concentrations for scenario 7 during low-flow conditions (150 $\mathrm{mg} / \mathrm{L})$ and scenario 8 during high-flow (550 mg/L) and lowflow conditions $(301 \mathrm{mg} / \mathrm{L})$.

The transport and movement of tracer concentration in Beaver Lake varied substantially between injection locations and flow conditions. In general, the duration of high tracer concentrations at the four intakes was relatively short when tracers were released at high-flow conditions (fig. 17) compared to releases during low-flow conditions (fig. 18). For scenarios 1-4, where tracers were placed in the more riverine upstream portion of the reservoir on March 17, 2002, during high-flow conditions, the tracer was quickly transported into the hypolimnion in the upstream portion of the reservoir and in the epilimnion and metalimnion further downstream in the reservoir, resulting in a sharp peak in concentration at the Beaver Water District intake and persistent lower concentrations in the three downstream intakes. For example, from the time that the tracer was first detected at the Beaver Water District intake until the peak concentration occurred was 6 days for scenario 1, 1 day for scenarios 2 and 4, and 5 days for scenario 3 . Concentrations generally dropped to below $100 \mathrm{mg} / \mathrm{L}$ approximately 20 days after the peak for scenarios 1-4 at the Beaver Water District intake. Concentrations in the three downstream intakes had much smaller peaks and maintained a concentration of approximately 15 to $20 \mathrm{mg} / \mathrm{L}$ for the remaining model period (fig. 17).

When tracers were introduced for scenarios 1-4 during low-flow conditions on August 7, 2001, most of the tracer remained in the upstream portion of the reservoir until midDecember when a storm event flushed most of the tracer downstream into the hypolimnion, mainly at greater depths than the downstream intakes, resulting in very low tracer concentrations at the Benton-Washington County Water, Madison- 


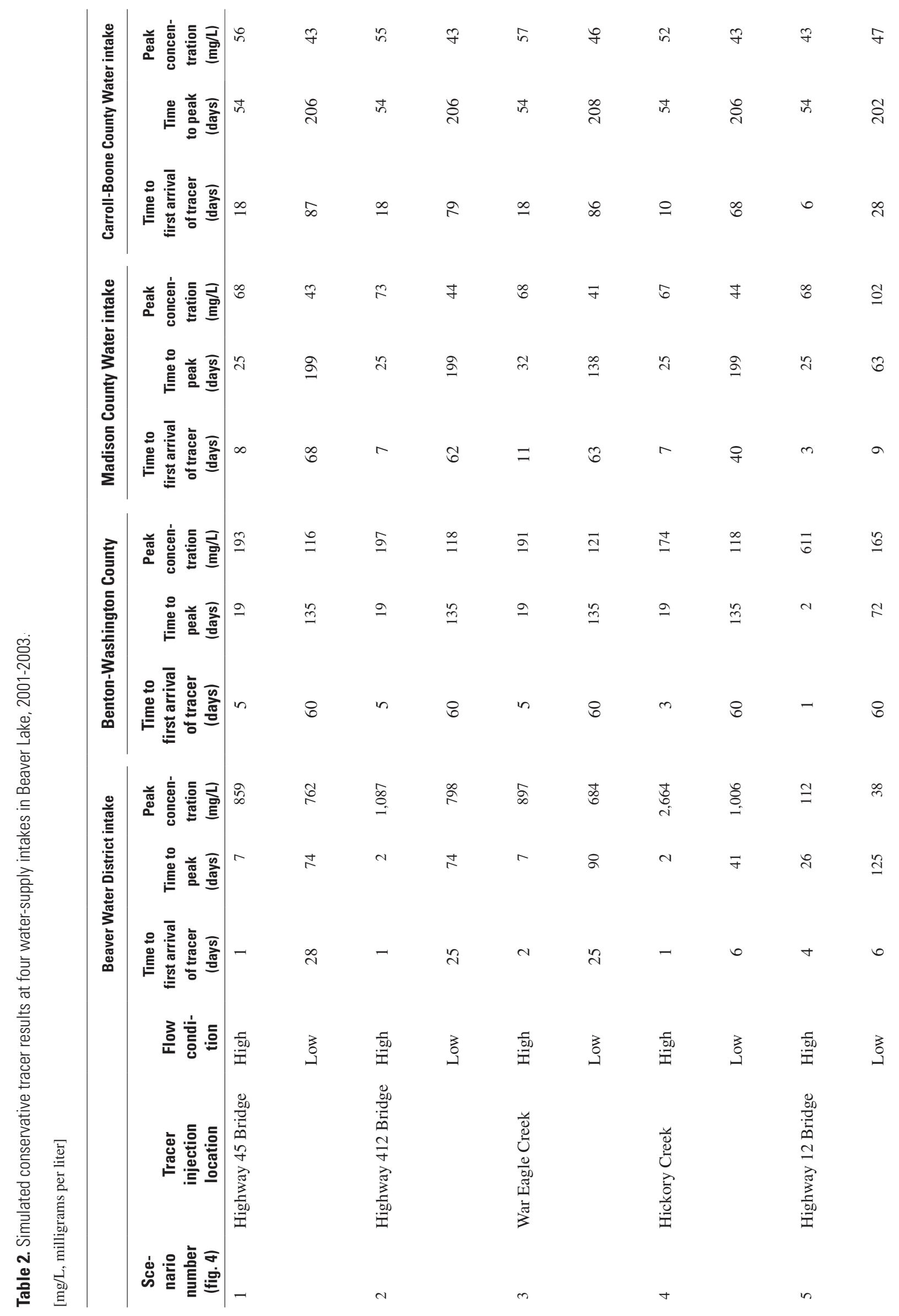


26 Application of a Two-Dimensional Reservoir Water-Quality Model of Beaver Lake, Arkansas, for the Evaluation of Simulated Changes in Input Water Quality, 2001-2003

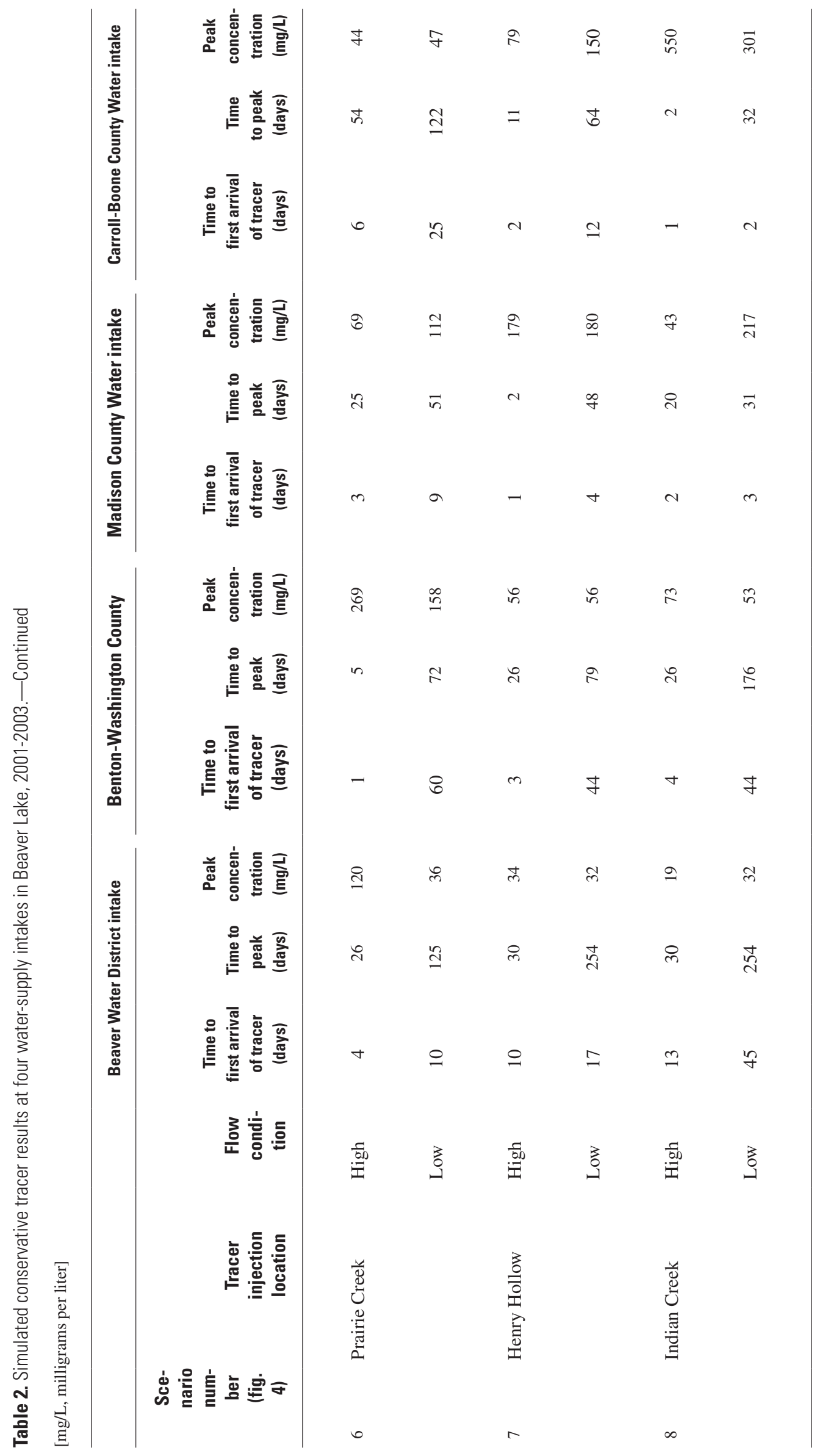



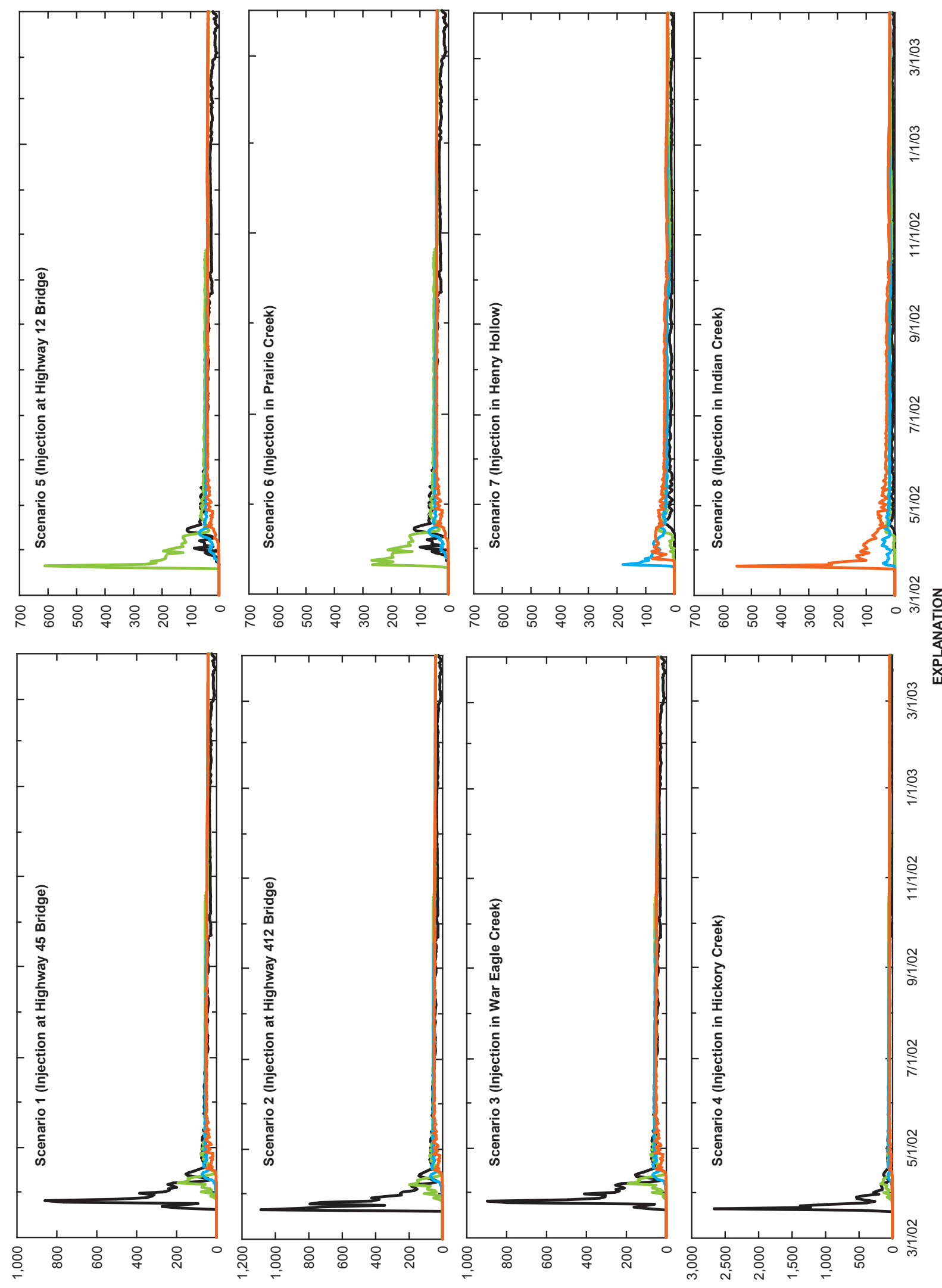

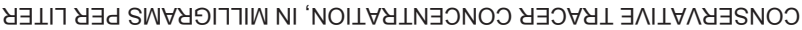

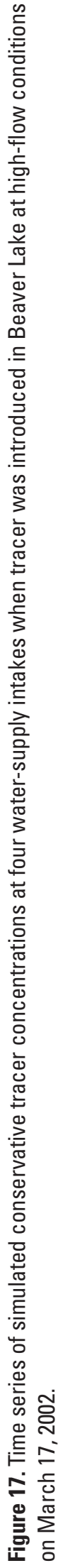



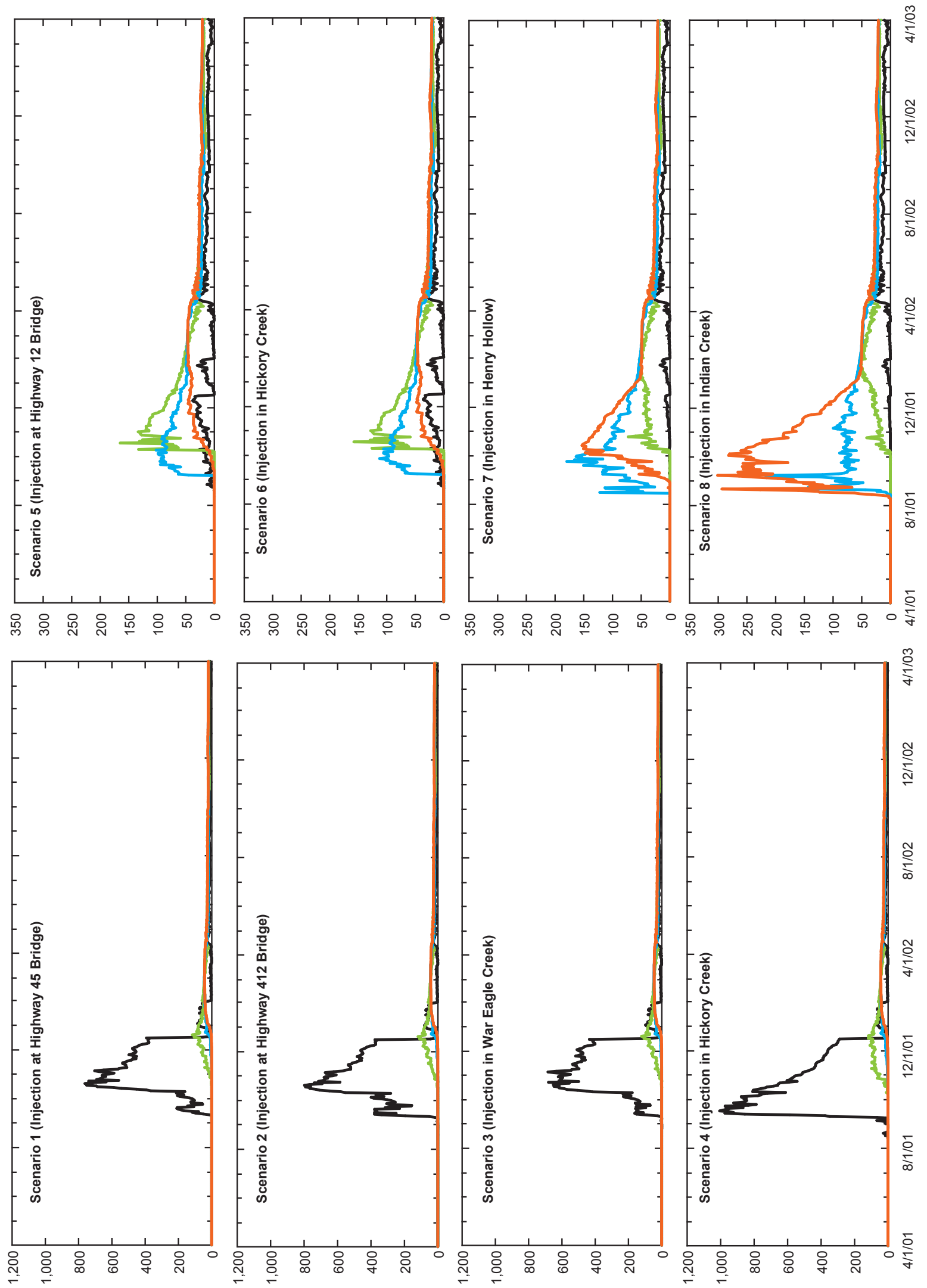

2
$\frac{2}{5}$
$\frac{2}{0}$
$\frac{1}{x}$

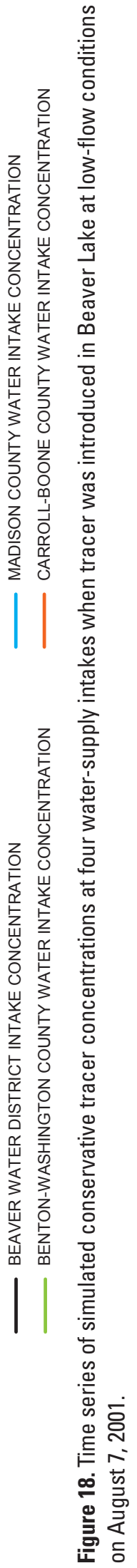

y 
County Water, and Carroll-Boone County Water intakes (fig. 18). Concentrations remained greater than $100 \mathrm{mg} / \mathrm{L}$ approximately 58 days following the peak concentration for scenarios 1-4 at the Beaver Water District intake (fig. 18).

The distribution of the tracer in the water column was considerably different for scenarios 5-8, where the tracer was placed in the more lacustrine, downstream portion of Beaver Lake, compared to scenarios 1-4. During high-flow conditions (March 17, 2002) stratification in the lake was not completely established, and most of the tracer was quickly transported into the hypolimnion of the lake at depths greater than the intakes, and a smaller portion remained in the epilimnion until the lake completely mixed in the following December. The results were sharp concentration peaks at the three downstream intakes followed by persistent concentrations ranging from 20 to $40 \mathrm{mg} / \mathrm{L}$ for the remainder of the modeling period (fig. 17). In comparison, when tracer was injected during low-flow conditions (August 7, 2001), most of the tracer remained in the epilimnion until the reservoir completely mixed in December and was distributed throughout the water column in the downstream portion of the reservoir. The tracer then was distributed throughout the hypolimnion in most of the lake after stratification in the reservoir formed in the following summer and fall. This resulted in high concentrations at the three downstream intakes for a relatively long period of time (approximately 4 to 5 months) followed by persistent concentrations at the intakes ranging from 20 to $40 \mathrm{mg} / \mathrm{L}$ for the remainder of the model period (fig. 18), similar to the concentrations observed when the tracer was injected during high-flow conditions (fig. 17).

\section{Model Limitations}

An understanding of model limitations is essential for effective use of reservoir models. The accuracy of the Beaver Lake model is limited by the simplification of complexities of the water quality and hydrodynamics within the reservoir, by spatial and temporal discretization effects, and by assumptions made in the formulation of the governing equations. Model accuracy also is limited by segment size, boundary conditions, accuracy of calibration, and parameter sensitivity. Model accuracy also is limited by the availability of data and by the interpolations and extrapolations that are inherent in using data in a model. Although a model might be calibrated, calibration parameter values are not necessarily unique in yielding acceptable values for the selected water-quality constituents, algal biomass, and reservoir water-surface elevation.

Another limitation of the Beaver Lake model is that it is a two-dimensional representation of a three-dimensional waterbody. The governing equations are laterally and vertically averaged within layers. Although the model may accurately represent vertical and longitudinal processes within the reservoir, processes that occur laterally, or from shoreline to shoreline perpendicular to the downstream axis, may not be properly represented.
Eddy coefficients are used to model turbulence in a reservoir in which vertical turbulence equations are written in the conservative form using the Boussinesq and hydrostatic approximations (Cole and Wells, 2003). Because vertical momentum is not included, the model may give inaccurate results where there is substantial vertical acceleration.

Some other limitations of the water-quality interactions in the model are that zooplankton or macrophytes are not included and the model uses simplistic sediment-oxygen demand computations. The zooplankton and macrophyte communities not represented in the model may have an effect on how the phytoplankton community or recycling of nutrients are simulated. Also, the complexities of the phytoplankton community and the dynamics of the community over time were simplified in the model by using four general phytoplankton groups (blue-green algae, green algae, diatoms, and flagellates). The model does not have a sediment compartment that models kinetics in the sediment and at the sediment-water interface. The simplistic sediment computation in the model places a limitation on long-term predictive capabilities of the water-quality portion of the model.

As mentioned earlier in the report, the evaluation of water clarity by changing inflow suspended solids also is limited by the model. Water clarity in the reservoir was determined by measuring turbidity and Secchi depth (Galloway and Green, 2006). However, turbidity and Secchi depth are not simulated in CE-QUAL-W2. In addition to inorganic solids, water clarity also is affected by the organic material and color in the water column. The CE-QUAL-W2 model of Beaver Lake does account for organic material in the water column, but not color effects. The analysis of suspended solids also is limited because although inorganic suspended solids were included in the calibrated model to simulate their affects on light extinction in Beaver Lake, they were not compared and adjusted to measured values in the reservoir.

\section{Summary}

Because of the importance of Beaver Lake, it is considered a primary watershed of concern in the State of Arkansas. Information is needed to assess water quality, especially nutrient enrichment, nutrient-algal relations, and turbidity and sediment issues within the system. In cooperation with the Arkansas Department of Environmental Quality, a previously calibrated two-dimensional, laterally averaged model of hydrodynamics and water quality was used for the evaluation of different nutrient and sediment loading and conservative tracer simulations for the period of April 2001 to April 2003. Nitrogen and phosphorus concentrations were increased and decreased and tested independently and simultaneously to examine the nutrient concentrations and algal response in the reservoir. Suspended-solids concentrations were increased and decreased to identify how solids, which can contribute to decreased water clarity, are distributed in the reservoir. These 


\section{Application of a Two-Dimensional Reservoir Water-Quality Model of Beaver Lake, Arkansas, for the Evaluation of Simulated Changes in Input Water Quality, 2001-2003}

results can be used in the development of nutrient and turbidity criteria and standards for Beaver Lake. The methods also can be used as a prototype for the assessment of water-quality criteria in other reservoirs. The Beaver Lake model also was evaluated using a conservative tracer. A conservative tracer was applied at various locations in the reservoir model to observe the fate and transport and how the reservoir might react to the introduction of a conservative substance, or a worst-case spill scenario. In particular, tracer concentrations were evaluated at the locations of the four public water-supply intakes in Beaver Lake.

Nutrient concentrations in Beaver Lake increased proportionally with increases in loads from the three main tributaries. An increase of 10 times the calibrated daily input nitrogen and phosphorus in the three main tributaries resulted in daily mean total nitrogen concentrations in the epilimnion that were nearly 4 times greater than the calibration concentrations at site L2 and more than 2 times greater the calibrated concentrations at site L5. Increases in daily input nitrogen in the three main tributaries independently did not cause substantial increases in concentrations of nitrogen in Beaver Lake. The mass of nitrogen entering Beaver Lake from each tributary independently was less because the volume of streamflow for each tributary was less than the three combined.

The greatest proportional increase in phosphorus concentrations in the lake occurred in the epilimnion at sites L3 and L4 and the least increase occurred at sites L2 and L5 when calibrated daily input phosphorus concentrations were increased independently from nitrogen. When orthophosphorus was increased independently from nitrogen in all three tributaries by a factor of 10 , daily mean orthophosphorus concentrations in the epilimnion of the reservoir were almost 11 times greater than the calibrated concentrations at sites L2 and L5, and 15 times greater in the epilimnion of the reservoir at sites L3 and L4. Phosphorus concentrations did not increase as much in Beaver Lake when nitrogen and phosphorus were increased simultaneously compared to when phosphorus was increased independently.

The greatest simulated increase in algal biomass (represented as chlorophyll $a$ ) occurred when nitrogen and phosphorus were increased simultaneously in the three main tributaries. On average, the chlorophyll $a$ values increased less than $1 \mu \mathrm{g} / \mathrm{L}$ when concentrations of nitrogen or phosphorous were increased independently by a factor of 10 at all three tributaries. The maximum increase in chlorophyll $a$ concentration in the epilimnion at site L3 in Beaver Lake was less than $4 \mu \mathrm{g} / \mathrm{L}$ when nitrogen or phosphorus was increased independently by a factor of 10 at all three tributaries, which was within the error of the calibrated model. In comparison, when nitrogen and phosphorus were increased simultaneously by a factor of 10 for all three tributaries, the chlorophyll $a$ concentration increased by about $10 \mu \mathrm{g} / \mathrm{L}$ on average, with a maximum increase of about $57 \mu \mathrm{g} / \mathrm{L}$ in the epilimnion at site L3 in Beaver Lake.

Changes in algal biomass with changes in input nitrogen and phosphorus were variable through time in the Beaver Lake model from April 2001 to April 2003. When calibrated daily input nitrogen and phosphorus concentrations were increased simultaneously for the three main tributaries, the increase in chlorophyll $a$ concentration was the greatest in the late spring and summer of 2002.

Changes in calibrated daily input inorganic suspended solids were examined because of the effect they may have on water clarity in Beaver Lake. TSS concentrations in Beaver Lake increased proportionally to increases in the input inorganic suspended-solids concentrations. The increase in TSS was greatest in the hypolimnion at the upstream end of Beaver Lake, and negligible changes were observed at the downstream end of the reservoir for all of the scenarios. An increase of 10 times the calibrated daily input concentration of inorganic suspended solids in all three tributaries resulted in an increase in daily mean TSS concentration of $39.1 \mathrm{mg} / \mathrm{L}$ in the epilimnion (more than 5 times the calibrated condition) and $107 \mathrm{mg} / \mathrm{L}$ in the hypolimnion (more than 10 times the calibrated condition) at site $\mathrm{L} 2$ and $2.08 \mathrm{mg} / \mathrm{L}$ in the epilimnion (similar to the calibrated condition) and $30.7 \mathrm{mg} / \mathrm{L}$ in the hypolimnion (more than 11 times the calibrated condition) at site L3.

To observe the fate and transport and how the reservoir would react to a simulated spill at various locations in Beaver Lake, a high concentration of conservative tracer was introduced into the model for a relatively short period of time (1 hour) at eight locations in the reservoir during high-flow (March 17, 2002) and low-flow (August 7, 2001) conditions. In general, the duration of high tracer concentrations at the four water-supply intakes was relatively short when tracers were released at high-flow conditions compared to releases during low-flow conditions. For scenarios 1-4, where tracers were placed in the more riverine, upstream portion of the reservoir, the tracer quickly was transported into the hypolimnion in the upstream portion of the reservoir and in the epilimnion and metalimnion further downstream in the reservoir during high-flow conditions. In comparison, when tracers were introduced for scenarios 1-4 during low-flow conditions, most of the tracer remained in the upstream portion of the reservoir until mid-December when a storm event flushed most of the tracer downstream into the hypolimnion, mainly at greater depths than the downstream intakes. The distribution of the tracer in the water column was considerably different for scenarios 5-8, where the tracer was placed in the more lacustrine, downstream portion of Beaver Lake, compared to scenarios 14. During high-flow conditions, most of the tracer quickly was transported into the hypolimnion of the lake at depths greater than the intakes, and a smaller portion remained in the epilimnion until the lake completely mixed in the following December. In comparison, when tracer was injected during low-flow conditions, most of the tracer remained in the epilimnion until the reservoir completely mixed in December and was distributed throughout the water column in the downstream portion of the reservoir. The tracer then was distributed throughout the hypolimnion in most of the lake after stratification in the reservoir formed in the following summer and fall. 


\section{References Cited}

Arkansas Department of Environmental Quality, 2006, Arkansas Pollution Control and Ecology Commission, Regulation 2: accessed September 30, 2006, at http://www.adeq.state. ar.us/regs/files/reg02_final_060623.pdf

Brossett, T.H. and Evans, D.A., 2003, Water resources data, Arkansas, water year 2002: U.S. Geological Survey WaterData Report AR 02-1, 461 p.

Brossett, T.H., Schrader, T.P., and Evans, D.A., 2005, Water resources data, Arkansas, water year 2004: U.S. Geological Survey Water-Data Report AR 04-1, 460 p.

Cole, T.M. and Wells, S.A., 2003, CEQUAL-W2: A two dimensional, laterally averaged, hydrodynamic and water quality model, version 3.1: U.S. Army Corps of Engineers Instruction Report EL-03-1, variously paginated.

Evans, D.A., Brossett, T.H., and Schrader, T.P., 2004, Water resources data, Arkansas, water year 2003: U.S. Geological Survey Water-Data Report AR 03-1, 450 p.

Galloway, J.M. and Green, W.R., 2006, Analysis of ambient conditions and simulation of hydrodynamics and waterquality characteristics in Beaver Lake, Arkansas, 2001 through 2003: U.S. Geological Survey Scientific Investigations Report 2006-5003, 55 p.

Haggard, B.E. and Green, W.R., 2002, Simulation of hydrodynamics, temperature, and dissolved oxygen in Beaver Lake, Arkansas, 1994-1995: U.S. Geological Survey WaterResources Investigations Report 02-4116, 21 p.

Harris, G.P., 1986, Phytoplankton ecology, structure, function, and fluctuation: Cambridge, Cambridge University Press, $384 \mathrm{p}$.

Helsel, D.R., and Hirsch, R.M., 1992, Statistical methods in water resources: Amsterdam, Netherlands, Elsevier, 522 p.

Porter, J.E., Evans, D.A., and Remsing, L.M., 2002, Water resources data, Arkansas, water year 2001: U.S. Geological Survey Water-Data Report AR 01-1, 396 p.

Reynolds, C.S., 1984, The ecology of freshwater phytoplankton: Cambridge, Cambridge University Press, 384 p.

U.S. Geological Survey, 2002, National land cover data set 1992 (NLCD): accessed August 12, 2002, at http://edc.usgs. gov/products/landcover.html

Wetzel, R.G., 2001, Limnology (3rd ed.): San Diego, Academic Press, 1006 p. 
